marife

dini araștırmalar dergisi

Turkish Journal of Religious Studies

cilt / volume: 17 • sayı / issue: 1 • yaz / summer 2017

\title{
$\varangle \mid$ Fıkıh Literatüründe Yükümlülük Kuramı Bağlamında "Lâ Be'se (Bih)" Kavramı
}

\author{
Hasan Özer \\ Yrd. Doç. Dr., Dumlupınar Üniversitesi İslami İlimler Fakültesi \\ İslam Hukuku Ana bilim dalı Öğretim Üyesi \\ hasan.ozer@dpu.edu.tr
}

Geliş Tarihi: 27.02.2017 • Yayına Kabul Tarihi: 21.03.2017

$\ddot{O} z$

Her ilmin kendine özgü bir dili ve terminolojisi vardır. Buna hâkim olmadan o ilimde ilerleme ya da onu yeterince anlama imkânı yoktur. Bu yüzden ıstılahlar konusunda eser yazmış olan Tehânevî gibi bazı âlimler bir ilmin terminolojisini kavradıktan sonra hocaya gidip ders almanın teberrük için veya gönüllülük esasına dayalı olabileceğini belirtir. Fıkıh, șerî ilimlerin en önemlilerindendir ve tabii olarak onun da kendine özgü bir dili ve terminolojisi vardır. Terimler, nesnelerin zihindeki tasavvurlarıdır. Bazı terimler birden fazla ilmin ortak kullanımındadır ve o ilme göre anlamları değișmektedir. Bu durum bazen karıșıklığa da sebep olabilmektedir. Dolayısıla kavramların hangi manada kullanıldığının doğru bilinmesi metnin düzgün şekilde anlaşılmasını sağlayacaktır. Bu yazıda, mendub, müstehab, mubah, mekruh, terk-i evlâ ve hilâf-ı evlâ gibi manalara gelen "lâ be'se"nin, kelime ve ıstılah tanımları yapılmıştır. İlk dönemden itibaren hangi anlamlarda kullanıldığı, dört mezhepten örnekler eşliğinde yükümlülük kuramı çerçevesinde ortaya konulmaya çalışılmıştır.

Anahtar kelimeler: Lâ be'se (bih), Mendub, Müstehab, Mekruh, Hilâf-ı evlâ ve Terk-i evlâ.

\section{The Concept of "La ba'sa (beh)" in The Context of Responsibility Theory in Fiqh}

Every science has its own language and terminology. Without dominating this terminology, there can be no progress in knowledge or opportunity to understand any science. Scholars such as Tahanawi (d. 1158/1745?), who wrote some books about technical terms, state that after fully understanding the terminology of a science, going to a teacher for receiving courses can only be based on the principles of blessing or volunteering (tatavvu'). Fiqh is one of the most important of religious sciences and naturally has its own language and 'terminology'. Terms are the concepts of subjects in the mind. Some terms are in common use of more than one science and their meanings change according to the science utilizes it. This can also cause some confusion. Therefore, knowing correctly in which meaning such terms are used will ensure an accurate understanding of a text. In this paper, the linguistic and terminological definition of "la ba'sa" is provided from the wide range of meanings such as mandub, mustahab, mubah, makruh, tark al-awla and khilaf al-awla. We tried to find out for which meanings it was used right from the first eras within the framework of responsibility theory with examples from four fiqh madhahib.

Keywords: La ba'sa Bih, Mandub, Mustahab, Makruh, Khilaf al-awla and Tark al-awla

\section{Atıf}

Özer, Hasan, "Fıkıh Literatüründe Yükümlülük Kuramı Bağlamında "Lâ Be’se (Bih)" Kavramı", Marife, 17/1 (2017): 1-27. 


\section{Giriş}

Sözlükte; "zarar, güçlük, yiğitlik, mahzur, hasar, ziyan, zahmet, zorluk, azap, şiddet, korku, fenalık, sıkıntı içinde olmak veya savaşta şiddetli harekette bulunmak" gibi anlamlara gelen be’s/"بأس" kelimesi¹ cinsini nefyeden "ل" edatı ile beraber kullanıldığı zaman "zararsız, kabul edilebilir, idare eder, önemli değil," "kalıbıyla ise "yapılabilir ve yapılmasında bir sakınca yoktur" gibi manalara gelmektedir. "لا يرون به بأسًا" ifadesi de "bu konuda bir sıkıntı ve bir zorluk görmemektedirler" demektir. ${ }^{2}$

Kur'ân-1 Kerîm'de "بأس" kelimesi "şiddet, çetin, hınç, güç, kuvvet, azap" gibi manalara gelmekte olup yedi yerde geçmektedir. ${ }^{3}$

Kanaatimizce bu kavramın çerçevesi şu şekilde belirlenebilir: Lâ be'se " ل بأس mekruh gibi kesin olmayarak yapılmaması istenen eylemleri, bazen de herhangi bir şeyin yapılmasındaki serbestliği ve yasaklı̆̆ konusunda kesin bir sonuca varılamayan davranışları ifade etmek amacıyla kullanılan ef âl-i mükellefîn ile ilgili bir kavramdır.

Lâ be'se "لأبأس" kavramı, Hz. Peygamber (s.a.v.) tarafından bizzat ve o zamandan günümüze kadar da kullanılagelen terim haline gelmiş bir ifadedir. Hadislerde değişik şekillerde geçen bu ifadenin açlklanmaya ve izaha ihtiyacı vardır. Söz konusu lafzın içerisinde zikredildiği bir hadis ile onunla bağlantılı diğer bir hadise değinebiliriz. Bizzat lâ be'se lafzının anıldığı hadis șöyledir:

"Kul, kendisinde beis olanı terk ettiği gibi beis olmayanı da terk etmedikçe muttakiler mertebesine ulaşamaz."

Hadiste yer alan "hakkında beis olan şeyler" haramlar; "beis olmayan şeyler" de ihtiyaç fazlası helaller şeklinde açıklanmıştır. Yani "kul haram bir şeyi işlemek korkusuyla haram olmayan ihtiyaç fazlası helal şeyi bırakmadıkça muttakiler derecesine erişemez" demektir. ${ }^{5}$ Nitekim hadis şârihi Münâvî (ö. 1031/1622) bu hadisi açıklarken şöyle der:

1 İsmail b. Hammâd el-Cevherî (ö. 393/1003), es-Sıhâh (thk. Halil Memun Şeyha), Beyrut 1426/2005, md. بأس s. 71; İbn Manzûr (ö. 711/1311), Lisânu'l-Arab, Dâru Sâdır, ts., md. بأس, VI, 20; Ebû'l-Bekâ elKefevî (ö. 1094/1683), el-Külliyyât (thk. Adnan Derviş-Muhammed el-Mısrî), Beyrut 1432/2011, s. 206; Muhammed Murtaza el-Hüseynî ez-Zebîdî (ö. 1205/1790), Tâcu'l-'arûs, Daru'l-Hidâye, ts. md. Xأس XV, 430.

${ }^{2}$ Ebû'l-Bekâ, el-Külliyyât, s. 816.

${ }^{3}$ Nisâ, 4/84; En'âm, 6/65; İsrâ, 17/5; Neml, 27/33; Mü'min, 40/29; Fetih, 48/16; Hadîd, 57/25.

4 Tirmizî, "Sifatü'l-kıyâme”, 19, İbn Mâce, "Zühd", 24; Beyhakî, es-Sünenüll-kübrâ (thk. Muhammed Abdülkadir Ata), Beyrut 1424/2003, V, 546.

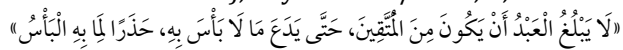

5 Zeynüddin Muhammed el-Münâvî (ö. 1031/1622), Feyzu'l-Kadîr şerhu'l-Câmiu's-sağîr, Kahire 1356, VI, 433; Hatipoğlu, Haydar, Sünen-i İbni Mâce Tercemesi ve Şerhi, İstanbul 2012, X, 487. 
"Bir görüşe göre sakıncasız şeyden maksat, lezzetli olan helal șeylerdir. Yani kul helal olan lezzetli, bol şeylere kendisini pek alıştırmamalıdır. Çünkü böyle alışırsa günün birinde helal yoldan bulamadıklarını, alışkanliğı yüzünden haram yollardan temin etme riski ile karşı karşıya kalır. Buna göre kul, bu tehlikeyi önceden sezerek harama düşmemek için helal olan lezzetli bol şeyleri terk etmedikçe muttakiler derecesine erişemez." 6

Konumuzla ilgili diğer bir hadiste ise şöyledir: Hz. Peygamber (s.a.v.), eşi Hz. Safiyye'nin (r.a.) hac dönüşü veda tavafı yapmadığını söylemesi üzerine, kendisine: "Bir sakınca yoktur (veda tavafi adetli kadından düşmüştür); yoluna devam et," buyurmuşlardır. ${ }^{7}$

Mâliki fakihi Şehabeddin el-Karâfî (ö. 684/1285), bu hadisin temelde aşağıdaki hadise dayandığını söyler: 8

"Helâl bellidir, haram bellidir, fakat aralarında bazı şüpheli șeyler vardır, insanların çoğu bunu bilmez. Kim bu şüpheli şeylerden korunursa dini ve ırzı için berâet almış olur. Her kim bu şüphelere düşerse harama düşer. Nitekim korunan bir yerin sinırinda hayvan otlatan çobanın hayvanlarını oraya kaçırması çok yüksek ihtimaldir. Dikkat edin! Her hükümdarın bir koruluğu vardır. Allah'ın koruluğu da, haram kıldığı şeylerdir. Dikkat edin! Bedende bir et parçası vardır, bu parça düzgün olursa bütün beden düzgün olur, bozuk olursa bütün beden bozuk olur. İşte o kalptir."

Konumuz ile alakalı olan bu hadisi, ulema, İslam'ın temelini oluşturan üç hadisten biri olarak görmüş, bir kısmı da İslam'ın üçte biri bu hadistir demişlerdir. ${ }^{10}$

Lâ be'se, Hz. Peygamber'den (s.a.v.) sonra, İmam Muhammed'in (ö.189/805) te'lifleri dâhil ilk dönemden günümüze kadar yazılan fikıh eserlerinde geçen, farklı

${ }^{6}$ Münâvî, Feyzu'l-kadîr, VI, 433; Hatipoğlu, Sünen-i İbni Mâce Tercemesi ve Şerhi, X, 487.

7 Buhârî, "Hac", 33.

8 Şihabuddin Ahmed b. İdris el-Karâfî (ö. 684/1285), ez-Zehîra, Beyrut 1994, XIII, 246-247.

${ }^{9}$ Buharî, "İman", 2; "Büyu", 37; Müslim, "Müsâkât", 41; Ebû Dâvûd, "Büyu”, 3; Tirmizî, "Büyu”, 1; Nesâî, "Edebü'l-kâdı̂”, 11; İbn Mâce, "Fiten”, 14. Aralarında bazı küçük farklılıklar olsa da söz konusu hadisi kütüb-i sitte imamlarının hepsi rivayet etmiştir. Bizim buraya aldığımız hadisin lafzı ise Müslim’e aittir.

10 Söz konusu ifade ile bağlantılı bu hadislerin açıklanmasına kısaca değinilmesinin faydalı olacağı kanaatindeyiz. Ebû Zekeriyya Yahya b. Şeref en-Nevevî (ö. 676/1277), el-Minhâc şerhu Sahîhi Müslim, Beyrut 1407/1987, XI, 27-28, isimli eserinde şöyle der: "Eşyalar helâl, harâm ve şüpheli olmak üzere üç kısımdır. Helal ve haramın hükmü bellidir. Şüpheli olanlar ise helal ve haramlığı kesin belli olmayanlardır. Bu sebeple bunların hükmünü çok kimse bilemez. Ancak ulema nassla veya kıyasla ya da istıshabla bunların hükmünü bilirler. Bir eșyanın veya bir eylemin helâl ve harâmlığı konusunda tereddütte kalır hakkında nass veya icma bulunmazsa o konu hakkında müctehid, ictihad eder ve onu şeri bir delille, haram veya helal dairesine dâhil eder. Bazen meselenin delili de ihtimallidir kesin değildir. Bu durumda da vera ve takva gereği onun yapılmasının terkedilmesidir. Ayni (ö. 855/1451) yukarda zikredilen "helal bellidir haram bellidir..." hadisini açlklarken şöyle demektedir: “... Sonuç olarak ulema burada şüpheli şeyleri izah ederken dört şey söylemiştir: Delillerin tearuzu, ulemanın ihtilafı, mekruh ve mubah olan şüpheliler. Mekruh helâl ile haram arasında bir yoldur. Mubah da helâl ile mekruh arasında bir geçittir. Zira onu çok işleyen mekruha düşer." (Ayrıntılı bilgi için bk. Ebû Muhammed Bedruddin Mahmud b. Ahmed el-Aynî (ö. 855/1451), Umdetü'l-kâri șerhu Sahîhi'l-Buhârî (thk. Abdullah Mahmud Muhammed Ömer), Beyrut 1421/2001, I, 465-466; XV, 235 ve devamı). 
anlamların iç içe geçtiği bir kavramdır. Hadis ilminde, cerh ve ta'dîl lafzı olarak, ravilerin değerlendirilmesinde terim olarak da kullanılan bu ifade, fıkıhta da farklı anlamlarda karşımıza çıkmaktadır.

Lâ be'se lafzı özellikle olumlu veya olumsuz bir beyanda bulunmanın zor olduğu meselelerde kullanılmıştır. Böylesi durumlara bu kelime ile bir çözüm yolu aranmıştır. Nitekim benzeri bazı kullanımlar başka konularda farklı kavramlar için de söz konusu olabilmektedir. Mesela, paranın yer almadığı takas tarzı alışverişlerde aynı cins mallarda ölçü olarak eşitlenebilir ve peşin olma şartı vardır. Bu kaideden hareketle ekmekle buğday ununun eşit olmaksızın peşin olarak değişimi hususunda Ebû Yûsuf (ö. 182/798) ve İmam Muhammed bunların ölçü birimi farklı olduğu için caiz olduğu kanaatindedirler. Zira ekmek sayı ile mübadele edilir (adedî), buğday unu ise ölçek ile işlem görür (keylî). Tercih edilen görüş de budur. Fakat Ebû Hanîfe (ö.150/767) bu alış-veriște "hayır yoktur" demek suretiyle, haramdır veya caizdir gibi kesin bir hüküm vermemiştir.11 Buradaki "hayır yoktur" ifadesi de lâ be'se benzeri bir kullanımdır.

Fıkıhla ilgili araștırmalarıyla meşhur Osmanlı âlimlerinden Âlim Muhammed b. Hamza'nın (ö. 1204/1706) lâ be'se kavramı üzerine "Risale fî isti'mali lâ be'se" adında yarım varak bir çalışması bulunmaktadır. ${ }^{12}$ Füru-ı fıkıh eserleri içerisinde dağınık vaziyette ve çokça bulunan söz konusu ifadeyle ilgili olarak adı geçen küçük risale dişında müstakil bir çalışmaya rastlanılamamıştır. Dolayısıyla bu konuda yeterli incelemenin bulunmayışı bizi böyle bir araştırmaya sevk etmiştir.

$\mathrm{Bu}$ kısa girişten sonra kavramın mezheplerin görüşleri çerçevesinde incelenmesine geçebiliriz.

\section{Lâ Be’se Kavramının Füru-ı Fıkıh Literatüründe Kullanımı}

Füru-ı fıkıh literatürüne genel olarak bakıldığında lâ be'se (bih) kavramının yaklaşık olarak "herhangi bir fiilin yapılmasında sevap da günah da yoktur" (لا يؤجر anlamında kullandığı anlaşılmaktadır. Bir eylemi yapmak ya da terk etmek arasında herhangi bir farkın bulunmadı̆̆ı, yapmak ile bir sevabın terk etmekle de bir günahın elde edilmeyeceği durumlar için kullanıldığı görülür. ${ }^{13} \mathrm{Bu}$ durumdan hareketle lâ be'se kelimesinin "müstehab"dan farklı bir manaya delalet ettiği söylenebilir. ${ }^{14}$

Ebû'l-Bekâ el-Kefevî (ö.1095/1684), Şerhu'l-Keydânî́den naklen:

\footnotetext{
11 Ebü'l-Hasen Burhânuddîn Ali b. Ebî Bekr el-Mergînânî (ö. 593/1197), el-Hidâye şerhu Bidâyeti'lmübtedî (thk. Ahmed Mahmud eş-Şehâde), Dımeșk 1427/2006 (Dâru'l-Farfur), III, 58.

12 İstanbul Üniversitesi Merkez Kütüphanesi, Nadir Eserler, Arapça bölümü, nr. 1502, vr. 56ª.

${ }^{13}$ Ebû'l-Bekâ, el-Külliyyât, s. 816.

14 Bedruddin Ebû Muhammed Mahmud b. Ahmed el-Aynî (ö. 855/1451), el-Binâye șerhu'l-Hidâye, Beyrut 1420/2000, II, 470; İbn Âbidîn, Muhammed Emîn (ö. 1252/1836), Reddü'l-muhtâr ale'dDürri'l-muhtâr şerhu Tenvîri'l-ebsâr (thk. Husamüddin b. Muhammed Sâlih Farfur), Dımeşk 1421/2000, I, 412-413; IV, 185-186, 202.
} 
“Müstehab: Hz. Peygamber'in gerek fiili olarak gerekse terk usulüyle yaptı̆̆ı davranışlardır. Örneğin, 'Lâ be'se bih'/'Bir sakınca yoktur' denilen yerde amel etmeyi terk etmek bu kabildendir ${ }^{15 "}$ demektedir. ${ }^{16}$

Yine Ebû'l-Bekâ, en-Nihâye'den yaptığı nakilde de şöyle demektedir:

"Lâ be'se kavramı bazen başında kullanıldığı cümlede o fili yapmanın onu terk etmekten evlâ olduğu yerlerde, bazen de bu fiili yapmanın vacip olduğu yerlerde kullanılır. Çünkü 'جناح/günah' kelimesi, be's 'بأس' kelimesi ile aynı manay $1^{17}$ ya da ondan daha kuvvetli bir anlamı beyan eder. Nitekim fiili yapmak vacip olmakla beraber 'vücûb ya da lâ be'se لا بأس manası' lâ cünâha/günah yoktur' siygası ile ifade edilmiștir. Kur'an-ı Kerim'de (meal olarak) şöyle geçmektedir: Şüphe yok ki, 'Safa ile Merve' Allah'ın koyduğu nişanlardandır. Her kim Beytullah'ı ziyaret eder veya umre yaparsa onları tavaf etmesinde kendisine 'bir günah yoktur.'18 Hâlbuki say yapmak Hanefilere göre vacip, Şafiilere göre ise farzdır."19

Ebü'l-Berekât en-Nesefînin (ö. 710/1310) el-Kâfî adlı eserinde müstehab ile lâ be'senin farklı anlamlarda kullanıldı̆̆ı görülür. Nitekim La be'se kavramı ahirete yönelik hükümler için kullanılmaktadır. Zira be's şiddet, zorluk ve problem anlamlarına gelir. Şiddetin ve zorluğun kaldırılmasına ihtiyaç olan yerlerde dile getirilir. ${ }^{20}$ Ayrıca diğer bir Hanefi fakihi Bedreddin Aynî (ö. 855/1451) de, camilerin süslenmesi ile ilgili konuyu tartışırken lâ be'se ifadesinin, "ne günah vardır, ne de sevap" anlamına geldiğine işaret etmektedir. Söz konusu bu çıarım, Nesefî'nin değerlendirmesi ile örtüşmektedir. Bu konu İmam Muhammed'in elCâmi'u's-sağîr adlı eserindeki kayda dayanmaktadır. ${ }^{21}$ Aynî, konuyu değerlendirirken "lâ be'se yani mekruh değildir (lâ yukrahu)" ifadesini kullanarak hükümler hiyerarşisindeki yerine işaret etmektedir. ${ }^{22}$

Hanefilere göre, lâ be'se çoğunlukla mubah veya terk-i evlâ (terkedilmesi yapılmasından daha uygun) anlamlarına gelir ki, bununla müstehabdan başka bir anlam kastedilmektedir. ${ }^{23} \mathrm{Bu}$ konu şu ifadelerle zapt altına alınmak istenmiştir:

15 Bu ifade aynı zamanda amel edilmesi konusunda lâ be’se bih denilmișse amel etmenin müstehab olduğu anlamını da içermektedir.

${ }^{16}$ Ebû'l-Bekâ, el-Külliyyât, s. 816.

17 Cünâh kelimesi be’s ile aynı derecede kullanıldığı zaman müstehab manasını ifade eder. Yapmanın ya da terk etmenin müstehab olduğu yerleri gösterir.

18 Bakara, 2/158. Heyet, Kur'ân-ı Kerim ve Açıklamalı Meâli, Türkiye Diyanet Vakfı Yayınları, Ankara 2005, s. 23.

${ }^{19}$ Ebû'l-Bekâ, el-Külliyyât, s. 816.

${ }^{20}$ Ebû'l-Berekât Abdullah b. Ahmed en-Nesefî (ö. 710/1310), el-Kâfî şerhu'l-Vâfî, Köprülü Ktp., Fazıl Ahmed Pașa Bölümü, nr. 612, vr. 23a; Aynî, el-Binâye, II, 470-471. Yani cevaz noktasında bir problem var ki böyle bir ifade kullanılmıștır.

${ }^{21}$ Muhammed b. Hasen eş-Şeybânî (ö. 189/805), el-Câmiu’s-sağîr, Beyrut 1406/1986, s. 121; Nesefî, elKâfî şerhu'l-Vâfî, Köprülü Ktp., Fazll Ahmed Paşa Bölümü, nr. 612, vr. 23a; Aynî, el-Binâye, II, 471472.

22 Aynî, el-Binâye, II, 472. قوله: لا بأس يعني لا يكره

23 İbnü'l-Hümâm (ö. 861/1457), Şerhu Fethi'l-Kadîr (thk. Abdurrezzâk Gâlib el-Mehdî), Beyrut 1415/1995, V, 500; VII, 241-242; Şihabuddîn Ahmed b. Muhammed el-Hamevî (ö. 1098/1687), 
“Kendisinde lâ be'se sözünün bulunduğu her ifade, terk-i evlâ anlamına gelir. Ancak bu konuda muteber (esah) olan görüş şudur ki, her yerde geçerli olabilecek küllî bir ilke bulunmamaktadır. Dolayısıyla böylesi durumlarda lâ $b e$ 'se'nin geçtiği yere bakılır; eğer caiz olduğuna dair bir delil varsa mükellef bu konuda muhayyerdir. Delil yoksa terk-i evlâdır."24

Lâ be'se çoğunlukla mubah ve terk-i evlâ anlamına gelmekle birlikte mendûb,25 müstehab ve mekruh gibi farklı manalarda da kullanıldığı iddia edilmiştir. ${ }^{26}$

Yukarda zikri geçen Âlim Muhammed b. Hamza risalesinde "lâ be'se" kavramının bazen "tercih edilmeyen (mercûh) caiz" yani terk-i evlâ anlamında, bazen yapılması tercihe şayan olan manasında kullanıldığını belirtmiştir. ${ }^{27}$

Ayrıca aşağıda lâ be’se kavramının Hanefi fıkıh literatüründeki kullanımından genişçe bahsedilecektir.

İmam Şafiî bu kelimeyi, mekruh ve müstehab değil, bizzat caiz manasında kullanmıştır. ${ }^{28}$ Şafî̀'lere göre, vefat eden kişinin, cenaze namazının kılınması ve kendisine dua edilmesi gibi belli görevlerin yerine getirilmesi için ölümünün duyurulmasında bir sakınca yoktur (lâ be'se). ${ }^{29}$ Yine Şafîi’lere göre, isteyen kimseye herhangi bir şeyin verilmesinde, Hz. Peygamber'in ve İslam'ın yüceltilmesi, iyi ahlakın ve güzel davranışların övülmesi için şiir yazılıp söylenmesinde bir sakınca yoktur (lâ be'se). ${ }^{30}$ Söz konusu davranışların hepsi caizdir ve bu cevaz la be'se ifadesiyle belirtilmiştir.

Malikiler, lâ be'se kavramının çoğunlukla mubah veya müstehab manasına geldiğini belirtirler. "Mükellefin, mubah fiilleri yaptığı durumlar için; lâ be'se, kullanılır."31 Bazı Mâlikîler ise lâ be'se'nin sadece mubah fiiller için kullanılabileceğini, müstehab manası ifade etmediğini beyan etmişlerdir. ${ }^{32}$ İmam

Gamzu 'uyûni'l-besâir șerhu kitabi'l-Eşbâh ve'n-nezâir, Beyrut 1405/1985 (Dâru'l-Kütübi'l-İlmiyye), II, 27-28; İbn Âbidîn, Reddü'l-muhtâr, IV, 202.

${ }^{24}$ Aynî, el-Binâye, XI, 561.

${ }^{25}$ Muhammed İbrahim el-Hafâdî, Mu'cmu garîbi'l-fikh ve'l-usûl, Kahire 1430/2009, s. 522.

26 İbnü'l-Hümâm, Fethi'l-Kadîr, V, 510; VII, 241-242; İbn Nüceym (v 870/1563), el-Bahru'r-râik șerhu Kenzi'd-dekâik (thk. Zekeriya Umeyrât), Beyrut 1418/1997, II, 210, V, 155; Şihabuddîn Ahmed b. Muhammed el-Hamevî (ö. 1098/1687), Gamzu Uyûni'l-besâir, Beyrut 1405/1985 (Dâru'l-Kütübi'lİlmiyye), II, 27-28; İbn Âbidîn, Reddü'l-muhtâr, I, 399, 401, V, 150; Nasîruddîn en-Nakîb, elMezâhibu'l-Hanefí, s. 378.

27 Âlim Muhammed b. Hamza, İstanbul üniversitesi Merkez Kpt., Nadir Eserler, Arapça bölümü 1502 numarada kayıtlı risalelerin içinde vr. 56a; eserin ayrıntıları için bk. Cici, Recep, Âlim Muhammed b. Hamza'nın Fıkıh Risâleleri, Bursa 2006, s. 46-47.

${ }^{28}$ el-Hafâdî, Mu'cemu garîbi'l-fikh ve'l-usûl, s. 522.

29 Muhyiddin Ebû Zekeriyya Yahya b. Şeref en-Nevevî (ö. 676/1277), Minhâcu't-tâlibîn (thk. Muhammed Tahir Şaban), Beyrut 1426/2005, s. 156.

${ }^{30}$ Muhammed b. Ahmed el-Hatîb eş-Șirbînî (ö. 977/1569), Muğni'l-muhtâc ilâ ma'rifeti meânî elfâzi'lMinhâc, Beyrut 1415/1994, Dâru'l-Kütübi'l-İlmiyye, I, 427.

31 Şemsüddin Ebû Abdillah b. Muhammed b. Abdirrahman et-Tirablusî el-Mağribî (ö. 954/1547), Mevâhibu'l-celîl fî șerhi Muhtasari'l-Halîl, Beyrut 1412/1992, I, 41.

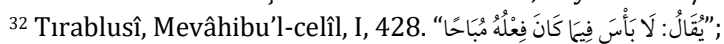


Malik'in Muvatta'da lâ be'se'yi çoğunlukla caiz olan hükümler için kullandığı da ifade edilmiştir. ${ }^{33}$

Mâlikî fakihi Sahnûn (ö. 240/854) "Ehli Kitabın haram olmayan yemeklerini ve kestikleri hayvanların etlerinin yenmesinde bir sakınca yoktur" der. Burada lâ be'se, ibaha için kullanılmıştır. ${ }^{34}$

Malikilere göre müezzin kamet getirdikten sonra, imam iftitah/tahrîme tekbiri getirinceye kadar cemaatin kısa bazı sözler söylemesinde bir sakınca yoktur (lâ be'se). Ancak tekbirden sonra konuşması caiz değildir. ${ }^{35}$

Şafiîlerin hilafına Malikilere göre, abdest aldıktan sonra havlu ve benzeri bir nesne ile kurulanmakta bir sakınca yoktur (lâ be'se). Burada da lâ be'se'nin mubahlık ifade ettiği anlașılmaktadır. ${ }^{36} \mathrm{Bu}$ konuda Hanefilerle Malikiler aynı görüştedirler. ${ }^{37}$

Bir kimsenin kurban kesme esnasında besmele ve tekbirden sonra " ربنا تقبل منا" "Rabbimiz bizden bunu kabul et", demesinde bir sakınca yoktur (lâ be’se). Burada lâ be'se ifadesinin, müstehab veya mubahlık manasına geldiği, kitabın şârihi tarafından açıklanmıştır. ${ }^{38}$ Yine Mâlikîlere göre ölçüyle, tartıyla ve sayı ile satılan malların toptan satılmasında bir sakınca yoktur (lâ be'se). Burada lâ be'se'nin, caiz manasına geldiği, Kayrevânînin er-Risâle'sine yazdığg şerhte Salih b. Abdissemî‘ el-Âbî (ö. 1335/1917) tarafından bizzat ifade edilmiştir. ${ }^{39}$

Hanbelîlere göre ise lâ be'se mubahlık ifade eden kavramlardandır. "Umulur ki yapılmasında bir sakınca/mahzur yoktur" anlamına gelir. "İsterse yapar (in şâe fe'ale)" lafzı da aynı şekilde ibaha ifade eder. ${ }^{40}$ Nitekim önceki paragrafta zikri geçen bu lafızların, mubahlık manasına geldiğine dair de Hanbelî mezhebinde icma bulunmaktadır. ${ }^{41}$

Ahmed b. Hanbel (ö. 241/855), "bunda bir sakınca yok ve umulur ki, böyle olmasında bir mahzur yok" dediği zaman "mubah olması uygun/mubah olduğu" anlamına gelir. ${ }^{42}$ Bunu teyit eden bazı örnekler zikredebiliriz:

Ahmed b. Hanbel'e kesilmeden kendi kendine ölen (murdar) hayvanın yününden/kılından yararlanılabilir mi diye sorulunca, "evet yararlanılabilir"

33 Örnekler için bk. Semâ‘în Halidî, “el-Menhecü’l-Fıkhî li’l-İmam-ı Malik fî̀l-Muvatta”, İslam Hukuku Araştırmaları Dergisi, sy. 9, Konya 2007, s. 307.

${ }^{34}$ Salih b. Abdissemî, es-Semeru'd-dânî, s. 405.

${ }^{35}$ Şihabuddin Ahmed b. İdris el-Karâfî (ö. 684/1285), ez-Zehîra, Beyrut 1994, II, 75.

${ }^{36}$ Karâfî, ez-Zehira, I, 289.

37 Aynî, el-Binâye, I, 253.

${ }^{38}$ Salih b. Abdissemî el-Âbî (ö. 1335/1917), es-Semeru'd-dânî fî takrîbi'd-dânî şerhu Risâleti İbn Ebî Zeyd el-Kayrevânî, Beyrut, ts., el-Mektebetü's-Sekâfiyye, s. 396.

${ }^{39}$ Salih b. Abdissemî, es-Semeru'd-dânî, s. 519.

${ }^{40}$ Meryem Muhammed Salih ez-Zâfirî, Mustelahâtu'l-mezâhibi'l-fıkhiyye, Beyrut 1422/2002 (Dâru İbni Hazm), s. 334.

41 Ebû Abdillah el-Hasen b. Hâmid, Tehzîbu'l-ecvibe (thk. Subhî es-Sâmirâî), Mektebetü'n-nahda 1408/1988, s. 133; Meryem Muhammed Salih ez-Zâfirî, Mustalahâtu'l-mezâhibi'l-fikhiyye, s. 334.

42 Necmüddîn Hahmed b. Hamdân b. Șebîb b. Hamdân en-Nemrî, Sıfetü’l-fetvâ ve'l-müftî ve'l-müsteftî, h. 1397, s. 91; Alauddîn Ebî’l-Hasen Ali b. Süleyman el-Madâvî, el-İnsâf fî marifeti'r-râcih min'l-hilâf alâ mezhebi'l-İmam Ahmed b. Hanbel, ts. Dâru İhyâi't-Türâsi'l-Arâbî, XII, 249; Hasen b. Hâmid, Tehzîbu'l-ecvibe, s. 334. 
cevabını vermiştir. Kendi kendine ölen kuşun tüyünden yararlanılabilir mi diye sorulunca ise, "o daha necistir; umarım kullanılmasında bir sakınca yoktur" demiştir. ${ }^{43}$

Yine Ahmed b. Hanbel'e oturarak veya yaslanarak nafile namaz kılan kișinin durumu sorulunca, bunun bir sakıncasının olamadığını beyan etmiștir. ${ }^{44}$ Soruya verilen lâ be'se bih "لأب بـ بـ cevabı, mubahlık ifade ettiğinin göstergesidir.

Ahmed b. Hanbel'e, simsara para ödemenin hükmü sorulunca şöyle cevap verdiği nakledilmektedir: "Müşteri, simsarın satın alacağı malın özelliklerini belirtir ve söz konusu malı kendisine bin dirheme satın alıverdiği takdirde simsara da yirmi bir dirhem vereceğini açıklarsa, bunda bir sakıncanın olmamasını (lâa be'se) umarım." 45 Hanbelilerin simsara para ödemenin caiz olmasıyla ilgili bu hükmü Hanefilerdeki mukayyet vekâlete ve ücretle özel iş gören kimseye benzemektedir. 46

Lâ be'se kavramının yükümlülük kuramı (ef'âl-i mükellefîn) ile çok yakın bir ilişkisi vardır. Bu kavram, müradifi sayılan hilâf-ı evlâ gibi diğer bazı kavramlarla yükümlülük kuramı ile ilgili sistemi muhafaza maksadıyla doğrudan ef'âl-i mükellefîn kategorisine dâhil edilmemiștir. ${ }^{47} \mathrm{Bu}$ sebeple lâ be'se'nin daha iyi anlaşılabilmesi için yükümlülük kuramının içeriği, hilâf-ı evlâ gibi benzer kullanımlar kısaca anlatılacaktır.

\section{Yükümlülük Kuramı Bağlamında $L a B e$ ’se Kavramı}

Mükellef bir Müslüman, Allah'a itaat etme ve asi olma konusunda denenir, itaat ederse sevaba nail olur ve günah ișlerse de azaba uğrar. Bu imtihanın vasıfları meșru ve gayri meșru olarak bir fiilin yapılması ve terkedilmesi ile ilintilidir. Meşru fiillerin vasfı dörttür: Farz, vâcib, sünnet/mendub ve müstehab. Bir de yapılması ve yapılmaması konusunda serbest bırakılan mubah vardır. Gayri meșru fiillerin de vasfı ikidir: Haram ve mekruh. Bunlara bir de dünyevî hükümlerden müfsit eklenebilir. ${ }^{48}$

Hüküm (ç. ahkâm) kelimesi sözlükte "fasl,49 isnat, engel, iyileștirmek amacıyla menetmek, düzeltmek, karar vermek" 50 manalarında ha-ke-me filinden

43 Hasen b. Hâmid, Tehzîbü'l-ecvibe, s. 133; Meryem Muhammed Salih ez-Zâfirî, Mustelahâtu'lmezâhibi'l-fıkhiyye, s. 334 .

${ }^{44}$ Muhammed b. Sâlih b. Muhammed el-Useymîn, eș-Şerhu'l-mümteni' alâ Zadi'l-müstekni', Dâru İbni'lCevzî, 1422, IV, 327; Meryem Muhammed Salih ez-Zâfirî, Mustelahâtu'l-mezâhibi'l-fıkhiyye, s. 334.

45 " Meryem Muhammed Salih ez-Zâfirî, Mustelahâtu’l-mezâhibi'l-fikhiyye, s. 335.

${ }^{46}$ Ayrıntılı bilgi için bk. Ebü’l-Fazl Abdullah b. Mahmud b. Mahmud el-Mevsılî (v. 683/1284), el-İhtiyâr lita'lîli'l-Muhtâr (thk. Muhammed Muhyiddin Abdülhamid), Mısır 1372/1952, II, 229-233, 75-77; Abdülkerim Zeydan, el-Medhal, Beyrut 1420/2005, s. 325-326.

47 Bedrüddîn Muhammed b. Bahadır Abdullah ez-Zerkeşî (ö. 794/1392), el-Bahru'l-muhît fî usûli'l-fıkh (thk. Abdülkadir Abdullah el-'Ânî), Kuveyt 1413/1992, I, 296-303.

${ }^{48}$ Nesefî, Flkhu'l-Keydânî, İstanbul Millet Ktp., nr. 1178, vr. 214b.

${ }^{49}$ Feyyûmî, el-Misbâhu'l-münîr, Kum h. 1405, I, 145.

50 Firûzâbâdî, el-Kâmûsu'l-muhît, Madde: حكم, s. 1415; Zebîdî, Tacu'l-a'rûs, Madde: حكم, XXXI, 510; İbn Fâris, Mu'cemu mekâyisi'l-lüğa (thk. Abdüsselam Muhammed Harun), Beyrut 1399/1979, Madde: 
mastar olarak; 51 ve "ilim, derin anlayıș,52 siyasi hâkimiyet, karar ve yargı"53 anlamlarında isim olarak kullanılmaktadır. ${ }^{54}$ Konumuz lâ be'se kavramı ile ilgili olması sebebiyle biz sadece fıkıhçıların hükümle ilgili görüşlerini kısaca açıklamak istiyoruz.

Fıkıh usulünün konusu hususunda görüş farklılıkları bulunmakla birlikte, şer'i hükümler ve şer'i delillerdir. Dolayısıyla bu ilim şerî̂ delillerden şerî̂ hükümler elde edilmesini, füru-l fikıh ise bu hükümlerin bilinmesini ve uygulanmasını ${ }^{55}$ konu edindiğinden hüküm kavramı fıkıhta meselelerin kendi etrafında döndüğü merkezi bir öneme sahip olmuş ve klasik literatürde bu bağlamda ıstılah anlamını kazanmıştır. ${ }^{56}$

Re'y ekolüne mensup Hanefi usulcüler ile mütekellim metodunu benimseyen usulcüler, şer'i hükmü farklı şekilde tarif etmişlerdir. Hanefî usulcülere göre hüküm “Allah'ın iktizâ, tahyîr ve vaz' (bağlantı kurma) bakımından mükelleflerin fillerine ilişkin hitabının neticesidir (eseru'l-hıtâb)."57 Mütekellim usulcüler, hükmü, ilk dönemde "Şâri'in kulların fiilleri ile ilgili hitabıdır"58 şeklinde tarif etmişlerdir. Ancak bu tarif eksik bulunup eleştirilere sebep olduğu için, sonraki usûlcülerden büyük bir çoğunluğu "Allah'ın taleb, tahyîr veya vaz' (bağlantı kurma) bakımından mükelleflerin fiilleriyle ilgili hitabıdır"59 şeklinde

حكم, II, 91; Feyyûmî, el-Misbâhu'l-münîr, Kum h. 1405, I, 145; Ali b. Muhammed e-Şerîf el-Cürcânî (ö. 818/1415), Kitabü't-ta'rifât (thk. Muhammed Abdurrahman el-Mara'şlî), Beyrut 14124/2003, s. 155-156.

51 Firûzâbâdî, el-Kâmûsu'l-muhît, s. 1415.

52 Muhammed b. Mükerrem İbn Manzûr, Lisânü'l-Arab, Dâru Sâdr, Beyrut ts., Madde: “حَ", XII, 140; İsmail b. Ömer b. Kesîr, Tefsîru'l-Kur'âni'l-Azîm (thk. Sami b. Muhammed Selâme), Daru't-Taybe 1420/1999, V, 216.

53 Firûzâbâdî, el-Kâmûsu'l-muhît, Madde: “حكم”, s. 1415; Zebîdî, Tacu'l-a'rûs, Madde: “حكم”, XXXI, 510.

${ }^{54}$ Firûzâbâdî, el-Kâmûsu'l-muhît, s. 1415.

55 Molla Hüsrev, Muhammed b. Ferâmuz (ö. 885/1485), Mir'âtü'l-usûl șerhu Mirkâtü’l-vusûl, Ergin Kitabevi, İstanbul ts., s. 21; Hâdimî, Ebû Saîd Muhammed, Menâfi'u'd-dekâik fî şerhi Mecâmi'ı'lhakâik, İstanbul 1303, s. 3; Atar, Fahrettin, Fıkıh Usûlü, İstanbul 1992, s. 4-5.

${ }^{56}$ Şahin, Osman, İslam Hukunda Fetva Usulü, Samsun 2002, s. 37 (Basılmamış Doktora Tezi, Ondokuz Mayıs Üniversitesi Sosyal Bilimler Enstitüsü); Beyânûnî, Muhammed Ebü’l-Feth, "Hüküm”, DİA, İstanbul 1998, XVIII, 466.

57 Molla Hüsrev, Mir'ât, s. 510; İbrahim Muhammed Selkînî, el-Müyesser fî usûli'l-fikh, Beyrut 1411/1991, s. 199; Ali Cuma Muhammed, el-Hükmü’ş-Şer'1yyu, Kahire 1427/2006, s. 48.

"الحكم: هو أثر خطاب الله المتعلق بأفعال المكلفين بالاقتضاء أو التخيير أو الوضع"

${ }^{58}$ Muhammed b. Muhammed b. Muhammed el-Gazâlî (ö. 505/1111), el-Mustasfâ min 'ilmi'l-usûl (thk. Muhammed Süleyman el-Eşkar), Beyrut 1418/1997, Müessetü'r-Risâle, I, 112; a.müellif., el-Menhûl min ta'lîkâti'l-usûl (thk. Muhammed Hasen Heyto), Dâru'l-Fikr, Dımeşk 1400/1980, s. 7; Taftâzânî, Sa'dudîn Mes'ûd b. Ömer, (ö. 793/1390), et-Telvîh 'ale’t-Tavdîh, Dâru'l-Kütübi'l-İlmiyye, Beyrut, ts., I, 13; Molla Hüsrev, Mir'ât, s. 510.

${ }^{59}$ Fahruddîn Muhammed b. Ömer er-Râzî, el-Mahsûl fî 'ilmi'l-usûl (thk. Taha Cabir Feyyaz el-Alvânî), Riyat 1400/1980, I, 107; Seyfüddîn Ebü'l-Hasen Ali el-Âmidî, el-İhkâm fî usûli'l-ahkâm, Mısır 1968, I, 135; Cemâlüddîn Osman b. Ömer İbnü'l-Hâcib (ö. 646/1249), Muhtasaru'l-Münteha'l-usûlî, Dâru'lKütübi'l-İlmiyye, Beyrut 1983, I, 220; Taftâzânî, et-Telvîh, I, 13; Muhibbullah b. Abdişşekûr (ö. 1119/), Müsellemü's-sübût (thk. Abdullah Mahmud Muhammed Ömer), Beyrut 1423/2002, I, 45-46; Tehânevî, Muhammed b. Ali, Keşşâfu istlahâti'l-funûn, Dâru'l-Kütübi'l-İlmiyye, Beyrut 1998, I, 515; Ali Cuma, el-Hükmü'ş-Şer'ıyyu, s. 39, 45. 
yeni bir tanımlama yoluna gitmişlerdir. ${ }^{60}$ Mesela "Ey inananlar! Akitleri yerine getiriniz"61 ayetinden, akitlerin yerine getirilmesinin vacib/farz olduğu hükmü çıkarılmaktadır. ${ }^{62} \mathrm{Bu}$ tariflere göre, Hanefî usûlcüler bu hitabın sonucuna, mütekellim usûlcüler ise bizzat hitabın kendisine hüküm demektedirler. ${ }^{63}$

Fıkıh literatüründe "ef âl-i mükellefîn" ifadesinin "teklifi hükümlerle" aynı anlamda kullanılması ${ }^{64}$ ve konumuzla ilgili olması sebebiyle teklifi hükümlere kısaca değinilecektir.

Fıkıh usulcüleri tarafından beş veya yedi esas terim üzerine kurulan yükümlülük kuramında dinen yapılması istenen fiiller talebin kesin ve bağlayıcı olup olmamasına göre farz (vacip) ve mendub, yapılmaması istenenler aynı ölçüte göre haram ve mekruh (tahrimi ve tenzihi), yapılıp yapılmaması serbest bırakılanlar ise mubah olarak nitelenmiştir. ${ }^{65}$ Usûlcülerin çoğunluğu teklifi hükümleri Şârî'in hitabına nispet ederek îcâb, nedb, ibâha, tahrîm ve kerâhe şeklinde beş kısma ayırırken Hanefiler bunu mükellefin fiiline nispetle farz, vacip, mendûb, mubah, tenzihen mekruh, tahrimen mekruh ve haram șeklinde yedi kısma ayırarak incelemişlerdir. ${ }^{66}$

Fıkıh literatüründe oluşum döneminden itibaren kullanılan lâ be'se kavramı zikredilen bu kategorilerle yakından ilișkilidir. Lâ be'se kavramının bu kategorilerden bir kaçını birden ifade edecek şekilde genel bir anlamda kullanıldığı görülmektedir.

Teklifi hükümlerden lâ be’se manasına gelenlerin tanımlarına kısaca bir göz atıp örneklerini verelim.

\section{A. Mendûb ve Müstehab}

Sözlükte "önemli bir şeye davet ve teşvik etmek, ölüye ağıt yakarken onun iyiliklerini saymak"67 gibi manalara gelen mendûb kelimesi "istenen, arzulanan, kendisine çağrılan şey" demektir. Fıkıh usulü terimi olarak mendub, şer'an yapılması kesin ve bağlayıcı olmaksızın istenen ve terkedilmesi dini açıdan kınanmayan fiilleri ifade eder. Diğer bir ifadeyle Şâri'in kesin olmayarak yapılmasını istediği işler veya failine yaptı̆̆ zaman sevap verilen, terk ettiği vakit

60 Âmidî, el-İhkâm, I, 135; Taftâzânî, et-Telvîh, I, 13; Selkînî, el-Müyesser, s. 198-203; Şahin, Fetva Usulü, s. 37; Beyânûnî, "Hüküm”, DİA, XVIII, 466.

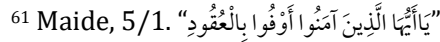

62 Atar, Fıkıh Usûlü, s. 114.

${ }^{63}$ Zeydan, Abdülkerim, el-Vecîz fî usûli'l-fikh, Beyrut 1418/1997, s.25; Beyânûnî, "Hüküm”, DİA, XVIII, 466.

64 Ögüt, Salim, “Ef âl-i Mükellefîn”, DİA, İstanbul 1994, X, 452.

${ }^{65}$ Koca, Ferhat, "Mekrûh”, DİA, Ankara 2003, XXVIII, 581; Dönmez, İbrahim Kâfi, "Mubah”, DİA, İstanbul 2005, XXX, 341.

66 Molla Hüsrev, Mir'ât, s. 512-513; Cürcânî, Ta'rifât, s. 156; Atar, Fıkıh Usûlü, s. 114-115; Ali Cuma, elHükmü'ş-Şer‘yyu, s. 49; Öğüt, Salim, "Ef'al-i Mükellefîn”, DİA, X, 452; Beyânûnî, "Hüküm”, DİA, XVIII, 467.

67 İbn Manzûr, Lisânü'l-Arab, md. "ندب", I, 723. 
ceza terettüp ettirilmeyen eylemdir. ${ }^{68}$ Söz gelimi borcun yazılmasını isteyen ayetteki ${ }^{69}$ talep mendub olarak yorumlanmıştır.

Hanefî usûlcüsü Sadrüşşerîa'ya (ö. 747/1346) göre, "kesin olmayan bir şekilde emredilen fiilin yapılması terkedilmesinden evlâ ise, dinde sürekli işlenen ve tutulan bir yol ise sünnettir, değilse nafile ve mendûbdur."70

Fıkıh usûlcülerinin tanımına göre mendûb sınırı içine giren durumların fıkıh literatüründe değişik kavramlarla ifade edildiği ve sözlük anlamları ile de ilişkilendirilerek bu terimlerin açıklandığı görülmektedir. Buna göre dinen yapılması tercihe şayan fiillere, Allah'a yaklaştıran bir davranış olması açısından "kurbet", sürekli yapılması ve tutulan bir yol olması veya Hz. Peygamber'e nispet edilmesi bakımından "sünnet", Allah'ın sevdiği bir fiil olması açısından "müstehab", farzlara ve vaciplere ilave olması yönünden "nafile" ve "fazilet", üzerine farz olmadığı halde mükellefin kendi isteğiyle yapması açısından "tatavvu", sevap vaad edilerek mükellefin teşvik edilmesi sebebiyle "murağğabün fih", dinen güzel bulunup teşvik edilmesi yahut sevap ve fazileti açıkça belirtilmiş olması cihetinden "mendûb", başkasına ulaşması ve ona faydalı olması açısından "ihsan" adı verilmiştir. ${ }^{71}$

Hanefiler, kesin olmaksızın dinen yapılması istenen fiilleri sünnet ve nafile diye ikiye ayırırlar. Birinci kısmın ayırıcı özelliği önce Hz. Peygamber'in (s.a.v.) ve ardından sahabenin davranışlarının örnek alınmasıdır. İkinci kısım, mükellefin dini bir vecibe olmadığı halde yapmak suretiyle sevap kazanacağı fiilleri ifade eder. Bunlar müstehab, mendûb, nâfile, tatavvu ve edep olarak da adlandırılır. ${ }^{72}$

Hanefîlere göre müstehab, yapılması tercih edilmekle beraber terki hakkında bir yasak bulunmayan ve dinde sürekli yapılmayan bir eylemdir. ${ }^{73}$ Buna mendûb, âdab, tatavvu, nafile ve sünnet de denir. ${ }^{74}$

68 Alauddin Muhammed b. Ahmed es-Semerkandî (ö. 539/1144), Mîzânü'l-usûl fî netâici'l-ukûl (thk. Zeki Abdülber), Katar 1404/1984, s. 28; Hasen b. Ammâr b. Ali eş-Şürunbilâlî (ö. 994/1069), İmdâdü'l-fettâh şerhu Nûri'l-îzâh (thk. Beşşâr Bekrî Arabî), Dımaşk ts., s.75; Molla Husrev, s. 512513; Atar, Fıkıh Usûlü, s. 255; Mahmud Hâmid Osman, el-Kâmûsu'l-mubîn fîıstlâhâti'l-usûliyyîn, Riyat 1423/2002, s. 288; Koca, Ferhat, "Mendûb", DİA, Ankara 2004, XXIX, 128; Dönmez, İbrahim Kâfi, "Mubah", DİA, İstanbul 2005, XXX, 341.

${ }^{69}$ Bakara, 2/282.

70 Sadrüşşerîa Ubeydullah b. Mes'ûd el-Mahbûbî (ö. 747/1346), et-Tavdîh şerhu't-Tenkîh (thk. Muhammed Adnan Derviş), Beyrut 1419/1998, II, 271; benzer ifadeler için bk. Molla Hüsrev, Mir'ât, s. 512.

${ }^{71}$ Fahruddin er-Râzî (ö. 606/1209), el-Mahsûl fî ilmi’l-usûl (thk. Taha Cabir Feyyâz el-Alvânî), Beyrut 1412/1992, I, 102-104; Şürunbilâlî, İmdâdü'l-fettâh, s. 75; Molla Husrev, Mir'ât, s. 512-513; İbn Âbidîn, Reddü'l-muhtâr, I, 412-413; Atar, Fıkıh Usûlü, s. 125-126; Ali Cuma, el-Hükmü'ş-Șerî, s. 5556; Abdürrezzak Abdurrahman Salim Ebû Umra, Hilâfu Evlâ ınde'l-usûliyyîn diraseten usûliyyeten mukâraneten, el-Âmu'l-Câmi'î 1432/2011, s. 23; Koca, “Mendûb”, DİA, XXIX, 128.

72 Ahmed b. Ebî Sehl es-Serahsî (ö. 483/1090), Usûlü’s-Serahsî (thk. Ebû'l-Vefâ el-Efkânî), Beyrut ts., I, 113-116; Abdülaziz el-Buhârî (ö. 730/1330), Keşfü'l-esrâr 'an Usûli Fahri'l-İslâm el-Bezdevî (thk. Muhammed el-Mutasım Billah el-Bağdâdî), Beyru 1414/1994, II, 567- 575; İbn Âbidîn, Reddü'lmuhtâr, I, 412-413; Meryem Muhammed Salih ez-Zâfirî, Mustelahâtu'l-mezâhibi'l-fikhiyye, Beyrut 1422/2002 (Dâru İbn Hazm), s. 38-42; Koca, “Mendûb”, DİA, XXIX, 129.

${ }^{73}$ Atar, Fıkıh Usûlü, s. 126; Erdoğan, Mehmet, Fıkıh ve Hukuk Terimleri Sözlüğü, İstanbul 2005, S. 431. 
Yazıda mendûb ile ilgili tanımın uzun tutulması birçok fiili ve birçok kavramı içine almış olmasının yanında çeşitli kelimelerle de ifade edilmiş olmasından dolayıdır.

Bütün bu açlklamalardan sonra, lâ be'se ile mendûb kavramlarının ortak yönü, her ikisinin de farz ve haram gibi kesin ve bağlayıcı hüküm ifade etmemeleridir. Müstehabı da yine aynı șekilde değerlendirebiliriz. Farkları ise her ne kadar mendûb ve müstehab kesin olmayarak yapılması tercih edilen fiiller için kullanılsa da lâ be'se genellikle yapılıp yapılmaması müsavi eylemler için kullanılmaktadır.

Aşağıda görüleceği üzere fıkıh literatüründe lâ be'se'nin "mendûb" ve "müstehab" anlamlarında kullanıldığı görülmektedir.

Burada lâ be'se ile ilgili örnekler, füru-ı fıkhın taharetten mirasa kadar olan klasik konu tasnifi çerçevesinde sıralanmıştır.

Fıkıh literatüründe lâ be’se'nin "mendûb" ve "müstehab" manasına geldiği örnekler:

Hanefi fıkıh literatüründe abdestin sünnetleri belirtilirken, abdest uzuvlarının tamamını kaplayacak şekilde üçer defa yıkanması sünnet, kalbin mutmain olması için abdest üzerine abdest almak niyetiyle üçten fazla yıkanmasında ise bir sakınca yoktur (lâ be'se). Bir defa ile yetinmek ise adet haline getirilmesi durumunda günah diye nitelendirilmektedir.

"Bir sakınca yoktur" (lâ be'se) ifadesi, genellikle terk-i evlâ manasına kullanılsa da abdest üzerine abdest mendûb hükmünde olduğu için burada mendûb anlamına gelmektedir. ${ }^{75}$

İbn Âbidîn, bazı tartışmaları naklettikten sonra konuyla ilgili net olarak şu ifadeyi kullanmaktadır: "Ben derim ki: Ulema abdest üzerine abdest almayı nur üzerine nur diye ta'lîl etmiştir. Çünkü sakınca yoktur (lâ be'se) ibaresi burada terk-i evla değil mendûb manasında kullanılmıştır."76

Başka bir örnekte ise Hanefîlere göre terâvih namazının cemaatle kılınmasında bir sakınca yoktur (lâ be'se). Çünkü o sünneti müekkededir,77 dolayısıyla buradaki lâ be’se kavramı mendûb manasınadır.

Müslümanların kabirleri, üzerlerine basmaksızın ziyaret edip onlara dua etmelerinde bir sakınca yoktur (lâ be'se). ${ }^{78}$

\footnotetext{
74 İbn Âbidîn, Reddü'l-muhtâr, I, 412-413; Ali Cuma, el-Hükmü’ş-Şerî̀, s. 55-56; Abdürrezzak, Hilâfu Evlâ, s. 23; ayrıntılı bilgi için bk. Meryem Muhammed Salih ez-Zâfirî, Mustelahâtu'l-mezâhibi'lfikhiyye, s. 340-342.

75 İbn Âbidîn, Reddü'l-muhtâr, I, 399; İbn Nüceym, el-Bahru'r-râik, II, 210, V, 155.

76 İbn Âbidîn, Reddü'l-muhtâr, I, 401.

77 Malik b. Enes (ö. 179/795), el-Muvatta, Hasan b. Şeybân rivayeti (thk. Takiyüddin en-Nedvî), Beyrut 1413/1992, I, 628-629; Âlim Muhammed b. Hamza, "Risâle fi istimali lâ be’se”, vr. 56a; Cici, Âlim Muhammed b. Hamza'ın Fıkıh Risâleleri, s. 46.

${ }^{78}$ Alauddin Ebû Bekir b. Mesud el-Kâsânî (ö. 587/1191), Bedâi'u’s-sanâi (Ali Muhammed Muavviz-Adil Ahmed Abdülmevcud), Beyrut 1424/2003, II, 559; Burhanüddin Ebî̀ı-Hasen Ali b. Ebî Bekr elMergînânî (ö. 593/1197), Kitabu't-Tecnîs ve'l-mezîd (thk. Muhammed Emin Hakkı), Beyrut 1424/2004, II, 293.
} 
Hz. Peygamber (s.a.v.) "Size kabir ziyaretini yasaklamıștım; artık ziyaret edebilirsiniz. Çünkü kabir ziyareti dünyada zühd sahibi yapar ve ahireti hatırlatır."79

Kabir ziyareti ve hükmü ile ilgili bu manaya gelen birçok hadis rivayet edilmiștir. $\mathrm{Bu}$ vb. hadislerin değerlendirilmesinden kabir ziyaretinin hükmünün müstehab olduğu söylenebilir. ${ }^{80}$ Fetâva-i Hindiyye'de "kabirlerin ziyaret edilmesinde bir sakınca yoktur..." hükmünü verdikten sonra Tehzîb adlı eserden "kabirlerin ziyaret edilmesi müstehabdır" cümlesini aktarmaktadır. Dolayısıyla, burada lâ be'se kavramı müstehab anlamında kullanılmıștır. ${ }^{81}$

Fakat Hanefiler kabir ziyaretinin hükmünü ifade ederken genellikle mendûb lafzı ile belirtmişlerdir. ${ }^{82}$ İbn Nüceym de, kabir ziyaretinin hükmünü söylerken bizzat lâ be'se ifadesinin, "mendûb" manasına geldiğini söylemiştir. ${ }^{83}$

Savaş esnasında devlet başkanının bir tasarrufu sayılan, askerleri motive etmek, onlara cesaret vermek veya onların üstün başarı göstermesi amacıyla "savaşta bir düşman askerini öldüren onun üzerinde çlkana sahip olur"84 ve "düşmanı öldüren, üzerinde bulduğu mallar veya bește biri hariç getirdiği ganimetten $^{85}$ geri kalanı kendisinindir" 86 demesinde bir sakınca yoktur (lâ be'se). ${ }^{87}$ Zira galibiyet için orduyu teşvik etmek mendûbdur.88 "Ey Nebi! Mü'minleri cihada teşvik et"89 ayeti de bunun delili kabul edilmektedir. Bu teşviklerin pratiği ise anlatıldığı gibi veya başka şekillerde de olabilir. Hepsinin hükmü mendûbdur. ${ }^{90}$

Lâ be'se ifadesi burada genellikle kullanıldığı anlamların ve terk-i evlânın (terkedilmesi yapılmasından daha uygun) dışında mendûb manasına gelmiștir.

79 İbn Mace, “Cenaiz”, 47. Ayrıca bk. Müslim, "Cenâiz”, 36.

80 Hadislerin değerlendirilmesi için bk. Ali b. Halef b. Abdülmelik b. Battâl el-Bekrî el-Kurtubî (ö. 449/1057), Șerhu Sahîhi'l-Buhârî, Riyad 1423/2003, III, 270 ve devamı; Yusuf b. Abdillah b. Abdilber en-Nemriî (ö. 463/1071), el-İstizkâr (thk. Salim Muhammed Ata-Muhammed Ali Muavviz), Beyrut 1421/1200, I, 183 ve devamı, V, 235 ve devamı; Aynı Müellif, et-Temhîd limâ fîll-Muvatta min'l-ma'ânî ve'l-esânîd (Mustafa b. Ahmed el-Alevî-Muhammed Abdülkebir el-Bekrî), III, 227-228, XVII, 209 ve devamı; Ahmed b. Ali b. Hacer el-Askalânî (ö. 852/1449), Fethu'l-bârî şerhu Sahîhi'lBuhârî, Beyrut 1399, III, 148 ve devamı; Bedruddin el-Aynî (ö. 855/1451), Şerhu Süneni Ebî Dâvûd (Ebû Münzir Halid b. İbrahim el-Mısrî), Riyad 1420/1999, VI, 190 ve devamı.

81 el-Feteva'l-Hindiyye, V, 350.

${ }^{82}$ Hasen b. Ammar b. Ali eş-Şürunbülâlî (ö. 1069/1659), İmdâdu'l-fettâh şerhu Nûri'l-îzâh ve necâti'lervâh (thk. Beşşar Bekrî Arabî), ts. s. 608; İbn Âbidîn, Reddü'l-muhtâr, IV, 365-366.

83 İbn Nüceym, el-Bahru'r-râik, II, 342.

${ }^{84}$ Malik, el-Muvatta', “Cihâd”, 18; Köse, Saffet, İslâm Hukukuna Giriș, İstanbul 2014, s. 201.

${ }^{85}$ Ganimetin tanımı, hükmü ve taksimi ile ilgili ayrıntılı bilgi için bk. Burhânuddîn Ebü'l-Hasen Ali b. Ebî Bekr el-Mergînânî, el-Hidâye şerhu Bidâtetü'l-mübtedî (thk. Ahmed Mahmud eş-Şehâde), Dımeşk 1427/2006 (Dâru'l-Farfur), II, 406-424; Erkal, Mehmet, "Ganimet", DİA, İstanbul 1996, XIII, 351354.

${ }^{86}$ Fıkıhta bu teşviki ifade eden kavrama "tenfîl” adı verilir. Ayrıntılı bilgi için bk. Mergînânî, Hidâye, II, 424-426; Yaman, Ahmet, “Tenfill", DİA, İstanbul 2011, XL, 451-452.

87 Ahmed b. Muhammed el-Kudûrî (ö. 428/1037), Muhtasaru'l-Kudûrî (thk. Said Bekdâş), Beyrut $1435 / 2014$, s. 364 .

${ }^{88}$ Mergînânî, el-Hidâye, II, 425-426.

${ }^{89}$ Enfâl, 8/65.

90 Mergînânî, el-Hidâye, II, 425; Aynî, el-Binâye, VII, 179; Âlim Muhammed b. Hamza, Risâle fî istimâli lâ be'se, vr. 56a; İbn Âbidîn, Reddü'l-muhtâr, XII, 590; Cici, Âlim Muhammed b. Hamza'ın Fıkıh Risâleleri, s. 46. 
Searahsî ise el-Mebsût'unda, lâ be'se'nin burada müstehab manasına geldiğini ifade etmiştir. Çünkü ona göre düşman askeri öldürülmeden "üzerindeki eşyalar öldürenindir" diye komutanın tenfil yapması müstehabdır. ${ }^{91}$

Hanefilere göre Yahudi ve Hıristiyanları hasta ziyaretinde bulunmakta bir sakınca yoktur (lâ be'se)..$^{92}$ Çünkü bu onlara bir iyilikte bulunmak manasına gelir. Onlara iyilik yapmak da yasaklanmamıştır. ${ }^{93}$ Zira Kur'an-ı Kerim'de “Allah, sizinle din uğrunda savaşmayan ve sizi yurtlarınızdan çıkarmayanlara iyilik yapmanızı ve onlara adil davranmanızı yasaklamaz. Çünkü Allah, adaletli olanları sever"94 buyrulmuştur. Hz. Peygamber'in (s.a.v.) de komşusu olan hasta bir Yahudi'yi ziyaret ettiği sahih rivayetlerle nakledilmiştir. ${ }^{95}$

Şafî̂ âlimlerinden İbn Dakîk el-'T̂yd (ö. 702/1302) ise hasta ziyareti ile ilgili şu kanaati belirtmektedir: "Zaruret olmazsa, mutlak manada hasta ziyaretinin hükmü çoğunluk ulemaya göre müstehabdır."96

Konuyla ilgili mutlak verilebilecek hükmün en aşağı derecesi müstehabdır. Dolayısıyla gayri Müslimler de bu hükmün içine dâhil edilebilir. Burada lâ be'se kavramına müstehab manası verildiği görülmektedir.

Hanefîlere göre musafaha yapmakta bir sakınca yoktur (lâ be’se). Çünkü onun sünnet (mendûb) olduğu konusunda şüphe yoktur, zira Hz. Peygamber'den (s.a.v.) beri devam edip gelen şüphe olmayan bir sünnettir. ${ }^{97}$

Buradaki sünnetten maksat mendûb olmasıdır. Âlim Muhammed b. Hamza da bu manada kullanılmasına örnek vermiştir. ${ }^{98}$

Yukarıda örneklerde de açıkça görüldügü üzere lâ be'se kavramı füru-ı fıkhın değişik konularında mendûb ve müstehab manalarında kullanılmıştır.

\section{B. Mubah}

Sözlükte "serbest bırakılmış, müsaade edilmiş ve yasaklığı kaldırılmış" manalarına gelen ${ }^{99}$ mubah fikıh usulü kavramı olarak "Şâri'in mükellefi yapıp yapmamakta serbest bıraktığı fiil" demektir. Buna câiz ve helâl de denir. Bu fiili yapana herhangi bir sevap terk edene ise ceza yoktur. ${ }^{100}$

\footnotetext{
91 Serahsî, el-Mebsût, X, 40-41.

92 ولا بأس بعيادة اليهودي والنصراني. Muhammed b. Hasen eş-Şeybânî, el-Câmiu's-sağîr, s. 482

93 İbn Mâze, Şerhu'l-Câmii’s-sağîr, s. 557; Mergînânî, el-Hidâye, IV, 167; Aynî, el-Binâye, XII, 244.

${ }^{94}$ Mümtehine, 60/8.

95 Buhârî, “Cenâiz", 78; "Merzâ", 4; Ebû dâvûd, “Cenâiz”, 5.

96 Takıyyuddin Ebû'l-Feth Muhammed b. Ali b. Vehb b. Mutî‘ el-Kuşeyrî İbn Dakîki'l-'Iyd (ö. 702/1302), İhkâmu'l-ahkâm șerhu Umdedi'l-ahkâm (thk. Mustafa Şeyh Mustafa-Müddesir Sündüs), Müessetü'rRisale 1426/2005, s. 486.

97 Mergînânî, el-Hidâye, IV, 155; Aynî, el-Binâye, XII, 194.

98 Âlim Muhammed b. Hamza, Risâle fi istimali lâ be'se, vr. 56a.

99 İbn Manzûr, Lisânu'l-Arab, Maddesi: “بوح", II, 416; Dönmez, "Mubah”, DİA, XXX, 341; Feyyûmî, elMisbâhu'l-münîr, I, 65.

100 Atar, Fıkıh Usûlü, s. 129; Ali Cuma, el-Hükmü’ş-Şerîi, s. 58; Abdürrezzak, Hilâfu Evlâ, s. 28; Dönmez, "Mubah", DİA, XXX, 341.
} 
Günümüzde bazı yazarların lâ be'se kavramını mubah manasında kullandıkları görülür.101

Mubah terimi üç durum için kullanılır:

a. Yapılıp terkedilmesi hususunda Şâri'in eşit seviyede açıklama yaptığı durumlar. Ramazan'da yolcunun oruç tutup tutmamakta serbest olması gibi.

b. Şâri'in hiçbir açıklama yapmadığı sükût ettiği durumlar.

c. Mubah ifadesi bazen de yapılması istenilen fiil için kullanılır ama bu mendûbdan farklıdır. İhramdan çıkarken saçları kısaltma yerine kazıtmanın tercih edilmesi gibi. ${ }^{102}$

Mubahın teklifi hükümlerden sayılıp sayılmayacağı tartışmalı bir husustur. ${ }^{103}$

Lâ be'se ile mubah arasındaki ilişki örneklerden de anlaşılacağı üzere çok açıktır. Çünkü her iki kavramın da kullanımında, bir eylemin yapılıp yapılmaması hususunda mükellefe seçme hakkı vermektedir.

Flkıh literatüründe lâ be’se'nin "mubah" manasına geldiği örnekler:

Fıkıh literatüründe, imam mescitte namaz kıldırırken kendisi, özel bir bölüm olarak yapılan mihrabın içine girmeksizin, sadece secdeyi mihraba denk gelecek şekilde yapmasında bir sakınca yoktur (lâ be’se). İmamın bu şekilde namaz kıldırması mekruh değildir. Fakat imamın mihrabın içine girip namazı orada kıldırması mekruhtur. Çünkü imamın namaz kıldırırken secde ettiği yere değil, ayaklarının durduğu yere itibar edilir. Zira mabetlerde özel yerlerin bulunması, Hıristiyan ve Yahudi din adamlarının durumuna benzemektedir. ${ }^{104}$ Ancak cemaat fazla olur, sıkışırsa imamın mihraba durarak namaz kıldırmasında bir sakınca yoktur (lâ be'se). Bu durumda bir özür bulunmaktadır.105 Burada lâ be'se kavramının mubah manasına geldiği görülmektedir.

Ayakta nafile namaz kılmaya başlayan kiși yorulduğu zaman bir bastona veya duvara ya da oturarak namazını tamamlamasında bir sakınca yoktur (lâ be’se). ${ }^{106}$ Çünkü bu kimse mazurdur. Fakat özürsüz olarak "ayakta başladığı namazı zikri geçen şekillerden biri ile tamamlarsa” mekruhtur, çünkü adap kurallarına uymamış olur.107 Özre binaen bu eylemin yapılması mubahtır. Burada lâ be'se mubah manasına gelmektedir. Zira nafile namazların oturarak da kılınabileceği belirtilmektedir.

101 Örnek ve ayrıntılı bilgi için bk. Muhammed Takî el-Osmânî, Buhusun fî Kazâyâ fikhiyye muâsıra, Karatşî, ts., Mektebetü Dâri'l-Ulûm, I, 342 ve devamı.

102 Ali Cuma, el-Hükmü’ş-Şer'î, s. 59-60.

103 Tartışmalar için bk. Dönmez, "Mubah”, DİA, XXX, 341 vd.

104 Muhammed b. Hasen eş-Şeybânî (ö. 189/805), el-Câmiu’s-sağîr, Beyrut 1406/1986, s. 86; Ömer b. Abdülaziz b. el-Mâze (ö. 536/1141), Şerhu'l-Câmi'i's-sağîr, Beyrut 1427/2006, s.144; Mergînânî, elHidâye, I, 235; Nesefi (ö. 710/1310), el-Kâfî, vr. 22b; Fahreddin Osman b. Ali ez-Zeylaî (ö. 743/1342), Tebyînu'l-hakâik şehu Kenzü'd-dekâik (thk. Ahmed İzzu İnaye), Beyrut 1420/2000, I, 413; İbn Nüceym, el-Bahru'r-râik, II, 45-46.

105 el-Mergînânî (ö. 593/1197), Kitabu't-Tecnîs, I, 520-521.

106 Muhammed b. Hasen eş-Şeybânî, el-Câmi'u's-sağîr, s. 107.

107 Ayrıntılar ve görüş farklılıkları için bk. İbn Mâze, Şerhu'l-Câmii's-sağîr, s. 180-181; Mergînânî, elHidâye, I, 270; Leknevî, en-Nâfiu'l-kebîr, s. 107. 
Üzerinde kral veya devlet adamlarının resimlerinin basılı olduğu paralar bulunduğu halde namaz kılınmasında bir sakınca yoktur (lâ be'se). Çünkü bunlar göze küçük görünürler. ${ }^{108}$ Burada da lâ be'se'nin mubah manasına geldiği görülmektedir.

Kuru yerde namaz kılan bir kimsenin, sıcaktan ve soğuktan korunmak için elbisesini serip üzerine secde etmesinde bir sakınca yoktur (lâ be'se). Çünkü bu durumda mekruhluğu gerektirecek bir durum bulunmamaktadır. Ebû Hanîfe'den rivayet edildiğine göre, kendisi de böyle yapmıştır. Bir gün kendisine bir adam geldi ve ey üstat böyle yapma, zira bu mekruhtur dedi. Ebû Hanîfe, sen nerelisin diye sordu. Harizmli olduğunu söyleyince, Ebû Hanîfe sizin mescidinizde sergi (hasır/ot) var mı? dedi. 0 da, evet! cevabını verdi. Ebû Hanîfe: Sergi üzerine secde caiz de kişinin elbisesi üzerine mi caiz değil? dedi. ${ }^{109}$ Kişinin elbisesini serip üzerine secde etmesinin mubahlığı açıktır, çünkü bu konuda bir yasak veya nehiy yoktur, dolayısıyla lâ be'se burada mubah manasına gelmektedir.

Namaz vakitlerinin dışında, cami eşyalarının çalınması ve kaybolması endişesiyle tedbir olarak kapısının kilitlenmesinde bir sakınca yoktur (lâ be'se). Burada lâ be'se'nin mubah manasına geldiği anlaşılmaktadır. ${ }^{110}$

Hanefîlere göre önünde asılı olan, Kur'ân-ı Kerîm ve kılıca doğru namaz kılmakta bir sakınca yoktur (lâ be'se). ${ }^{111}$ Çünkü bunlar kendisine ibadet edilen şeylerden değildir. Namaz kılarken önde herhangi bir şeyin bulunmasının mekruh olması ise tapınma endişesi bulunan resim heykel vb. nesnelerden dolayıdır. ${ }^{112}$ Bazı âlimler, Kur'an-ı Kerîm'in, yere konulup, ona yönelerek namaz kılınmasını mekruh saymaları ise tapınma endişesinden değil, sadece ona karşı edepte kusur söz konusu olması sebebiyledir. ${ }^{113}$ Burada da lâ be'se'nin mubah anlamına geldiği görülmektedir.

İmam Muhammed'in i'tikâfa giren kişi ile ihramlı kişiyi karşılaştırmasında lâ be'se lafzının mubahlık ifade ettiğinin örneklerini görmek mümkündür. İtikâfa giren kişi helal kapsamındaki elbiselerden dilediğini giyebilir, yiyeceklerden canın istediğini yiyebilir ve güzel kokulardan hoșuna gideni kullanabilir, bunda bir sakınca yoktur (lâ be'se). Ama ihramlı kişi, elbise giyemez, herhangi bir koku kullanamaz. ${ }^{114}$ Burada lâ be'senin ibaha ifade eden fiiller için kullanılmasından dolayı mubahlık manasına geldiği anlaşılmaktadır.

Hanefîlere göre kocanın i'tikâf için eșine izin vermesinde bir sakınca yoktur (lâ be'se), ancak izin verdikten sonra hanımının i'tikâfına engel olamaz. ${ }^{115}$ Yine aynı şekilde Hanefîlere göre i'tikâfta olan kimsenin uyumasında bir sakınca yoktur (lâ

\footnotetext{
108 Mergînânî, Kitabu't-Tecnîs, I, 527.

${ }^{109}$ Ayrıntı ve deliller için bk. Mergînânî, Kitâbu't-Tecnîs, I, 533.

110 el-Aynî, el-Binâye, II, 470.

111 Muhammed b. Hasen eş-Şeybânî, el-Câmiu's-sağîr, s. 88.

112 Mergînânî, el-Hidâye, I, 235; İbn Mâze, Şerhu'l-Câmii's-sağîr, s. 144.

113 Zeyleî, Tebyînu'l-hakâik, I, 417; İbn Nüceym, el-Bahru'r-râik, II, 56.

114 Muhammed b. Hasen eș-Şeybânî (ö. 189/805), el-Asl (thk. Ebü'l-Vefâ el-Efgânî), Beyrut 1410/1990, II, 244; Ahmed b. Muhammed Nasîruddîn en-Nakîb, el-Mezâhibu'l-Hanefî, Riyad 1422/2001, Mektebetü'r-Rüșd, I, 377.

115 Muhammed b. Hasen eş-Şeybânî, el-Asl, II, 244.
} 
be’se). Konuşmak, küfürleşmek ve kavga etmek i'tikâfı bozmaz. Ancak o böyle günah olan şeyleri bile bile kasıtlı olarak yapmamalıdır. ${ }^{116}$ Buradaki her iki hükmünde uygulamasından lâ be'senin mubah manasına geldiği anlaşılmaktadır.

Erkeklerin gerek oruçlu olsun gerek olmasın, süslenme gayesiyle değil de tedavi amaçlı sürme çekmesinde bir sakınca yoktur (lâ be'se). Çünkü süslenmek kadınlara ait bir eylemdir, denilmektedir. Aynî, bazı rivayetlerde bu konu da şöyle denildiğini aktarmaktadır: "Tedavi amacıyla erkeklerin siyah sürme çekmesi mubahtır, süslenmek için caiz değildir."117 Lâ be'se'nin burada mubah manasına geldiği görülmektedir, zira tedavi bir ihtiyaçtır, ihtiyaçların giderilmesi ise karşılanması gerekir.

İbn Mâce'nin es-Sünen'inde rivayet edilen bir hadiste "bir hayvanın iki hayvan karşılığında peşin olmak şartıyla takas yapılmasında bir sakınca yoktur (lâ be'se)" diyor. ${ }^{118}$ Fikıh kitaplarında bu hadis zikredildikten sonra, vadeli olarak satılması ise mekruhtur diye hüküm verilmiştir. ${ }^{119}$ Dolayısıyla hadiste geçen (lâ be'se) mubah anlamında düşünülebilir.

Hanefîlere göre gübrenin satılmasında bir sakınca yoktur ( $l a ̂ b e$ se), zira o hukuken meşru ve faydalanılabilen (müntefa'un bih) bir maldır. Çünkü tarlaya atıldığı zaman üründeki verimlilik artmaktadır. Dolayısıyla gübre özü itibariyle necis (necisü'l-'ayn) olmasına rağmen satışına cevaz verilmiştir. ${ }^{120}$ Burada "bir sakıncası yoktur" ifadesi; satış akdi geçerlidir ve bayiin mülkü demektir. ${ }^{121}$ Dolayısıyla lâ be'se'nin mubah anlamına geldiği görülmektedir.

Hanefîlere göre kesilmeden kendiliğinden ölen hayvanın kemik, sinir, yün, boynuz, tüy ve kıllarının satılmasında ve bunlardan faydalanılmasında bir sakınca yoktur (lâ be'se).122 Zira bunlarda canlılık olmadığı için ölüm de söz konusu olamaz. Dolayısıyla bu zikredilen nesneler, kendilerinde kan ve hayat olmadığı için temiz kabul edilmektedir. Eti yensin veya yenmesin hayvanların, kemikleri, boynuzları, dişleri, tırnakları, yünleri ve kılları temizdir. Hayvanların şer'i usullere göre kesilmiş olması şart değildir. ${ }^{123}$ Dolayısıyla burada lâ be’se ifadesi, emredici veya nehyedici bir açıklama söz konusu olmadığı için mubah anlamına geldiği görülmektedir.

Hanefîlere göre boğazlanmadan kendiliğinden ölen hayvanın derisi, tabaklandıktan sonra satılması ve ondan yararlanılmasında bir sakınca yoktur (lâ be'se). ${ }^{124}$ Çünkü tabaklandıktan sonra deri temiz olur. İbn Abbas'ın (r.a.) rivayet

\footnotetext{
116 Muhammed b. Hasen eş-Şeybânî, el-Asl, II, 245.

117 Aynî, el-Binâye, IV, 71.

118 İbn Mâce, "Ticârât", 56.

${ }^{119}$ Ayrıntılı bilgi için bk. Aynî, el-Binâye, VIII, 273.

120 Muhammed b. Hasen eș-Șeybânî, el-Câmiu's-sağîr, s. 480; İbn Mâze, Șerhu'l-Câmii's-sağîr, s. 554; Mergînânî, el-Hidâye, IV, 156; İbnü'l-Hümâm, Fethu'l-kadir, VI, 425, 427; VII, 121-122; el-Fetâva'lHindiyye, Dâru'l-Fikir 1411/1991, III, 116, 202.

${ }^{121}$ Leknevî, en-Nâfiu'l-kebîr, s. 480.

122 Muhammed b. Hasen eș-Șeybânî, el-Câmiu's-sağîr, s. 329.

123 İbn Mâze, Şerhu'l-Câmi'i's-sağîr, s. 426; Mergînânî, el-Hidâye, I, 106; III, 12; aynı mlf., Kitâbü't-Tecnîs, I, 261-262; II, 12; İbnü'l-Hümâm, Fethu'l-Kadîr, VI, 427; Leknevî, en-Nâfi'u'l-kebîr, s. 329.

${ }^{124}$ Muhammed b. Hasen eş-Şeybânî, el-Câmi'u’s-sağîr, s. 329.
} 
ettiğine göre "Hz. Peygamber (s.a.v.), kendiliğinden ölmüş bir hayvanın sadece yenilmesini haram kılmıştır, fakat derisi, kılı ve yününün kullanılmasında bir sakınca yoktur (lâ be'se)"125 buyurmuștur. ${ }^{126}$ Söz konusu uygulamalardan lâ $b e$ 'se'nin burada mubah anlamında kullanıldığı görülmektedir.

Hanefîlere göre tedavi amacıyla iğne yaptırılmasında bir sakınca yoktur (lâ be'se). ${ }^{127} \mathrm{Bu}$ konuda hadisler de mevcuttur. ${ }^{128}$ Çünkü tedavi olmanın mubahlığ konusunda icma vardır.129 Lâ be'se'nin burada mubah manası ifade ettiği görülmektedir.

Hanefîlere göre beytülmalden kâdî için maaş takdir etmekte bir sakınca yoktur (lâ be'se), ${ }^{130}$ caizdir. Çünkü Hz. Peygamber (s.a.v.) Attab b. Esîd (r.a.) Mekke'ye ve Hz. Ali'yi (r.a.) Yemen'e görevlendirdiği zaman kendilerine maaş takdir etmiştir. ${ }^{131}$

Ayrıca kâdî’nin Müslümanların hakkı için başka işlerde çalışması yasaklanmıștır. Dolayısıyla nafakası beytülmalden karşılanır. Eğer kâdî, nafaka için başka işlerde çalışırsa farz olan hüküm verme eylemini yerine getirmesi mümkün olmayacaktır. Kazanç elde etmekle ilgilenmesi görevini yapmaya engel teşkil edecektir. Kâdî'nin hüküm verme işine kendisini tahsis etmesi nafakasının da beytülmalden karşılanmasını gerektirmektedir. ${ }^{132} \mathrm{Bu}$ uygulama ifadelerden lâ be'senin mubah manasına geldiği açıkça görülmektedir.

Fıkhın farklı konularından verilen örneklerde, lâ be'se ile ilgili kullanımları bir bütün olarak düşünüldüğü zaman burada hepsinin mubah manasına geldiği görülmektedir. Çünkü verilen örneklerde her ne kadar lâ be'se ifadesi kullanılsa da bazı yerlerde açık hükümleri mubah olarak belirtilmiştir. Bütün bunlar dikkate alınarak örnekler incelenip lâ be'senin mubah anlamına geldiği tespit edilmiştir.

\section{Mekrûh}

Sözlükte "çirkin bulmak, kötü görmek, istememek; meşakkat, sıkıntı, zorluk" gibi anlamlara gelen ${ }^{133}$ mekruh, bir fıkıh usûlü terimi olarak "Şari'in yapılmamasını kesin ve bağlayıcı olmayan bir tarzda istediği fiillerle ilgili hitabıdır" şeklinde tarif edilir. ${ }^{134}$ Bazı âlimlere göre ise mekruh "işlemeyip terk edenin övüldügü, yapanın ise kınandığı fiillerdir."135

\footnotetext{
125 Sünen-i Dârakutnî, I, 47, 48.

126 Mergînânî, el-Hidâye, I, 105-106; III, 12; Mergînânî, Kitâbu't-Tecnîs, I, 261-262; İbnü'l-Hümâm, Fethu'l- Kadîr, VI, 426; Aynî, el-Binâye, VIII, 168; Leknevî, en-Nâfi'u'l-kebîr, s. 329.

127 Muhammed b. Hasen eş-Șeybânî, el-Câmiu's-sağîr, s. 484.

128 Buhârî, "Tıp", 1; Ebû dâvûd, "Tıp", 1; Tirmizî, "Tıp”, 2; İbn Mâce, "Tıb”, 1.

129 İbn Mâze, Şerhu'l-Câmii's-sağîr, s. 560; Mergînânî, el-Hidâye, IV, 172;

130 Muhammed b. Hasen eş-Şeybânî, el-Câmi'u's-sağîr, s. 484.

${ }^{131}$ Cemalüddin Ebû Muhammed Abdullah b. Yusuf b. Muhammed el-Zeylaî (ö. 762/1361), Nasbu'r-râye liehâdîsi'l-Hidâye (thk. Muhammed Avvâme), Beyrut 1418/1997, IV, 285-286.

132 İbn Mâze, Şerhu'l-Câmii's-sağîr, s. 561; Mergînânî, el-Hidâye, IV, 172-173.

133 İbn Manzûr, Lisânu'l-Arab, Maddesi “sر”, XIII, 514; Koca, Ferhat, "Mekrûh”, DİA, Ankara 2003, XXVIII, 581.

134 Râzî, el-Mahsûl, I, 113; Abdürrezzak, Hilâfu Evlâ, s. 21; Koca, “Mekruh”, DİA, XXVIII, 581.

135 Ali Cuma, el-Hükmü’ş-Şer î, s. 57-58.
} 
Gazzâlî, mekruh lafzının fakihler arasında farklı manalarda kullanıldığını belirtmektedir. Bunlardan birisi de "Yasaklanmış olmasa da en uygun olanın terkedilmesi (terkü'l-evlâ)" anlamında kullanılmasıdır. Mesela kuşluk namazının kılınmamasının mekruh sayılması bu hususta bir yasaklama bulunmasından dolayı değil, faziletinin büyüklüğü sebebiyledir. ${ }^{136}$

Hanefiler ise mekruhu "Şâri'in zannî bir delil ile terkedilmesini istediği fiildir" şeklinde tanımlayıp, "tahrimen" ve "tenzîhen" olmak üzere iki kısma ayırarak hükmünü de buna göre belirlemeye çalışmışlardır. ${ }^{137}$

Tahrîmen mekruh, Şâri'in terkedilmesini kesin ve bağlayıcı tarzda istediği fiillerdir, Ancak bu talep zannî bir delil olan haber-i vahidle sabit olduğu için fiiller haram değil tahrîmen mekrûh kabul edilmiștir. ${ }^{138}$ Tahrimen mekruha, başkalarının devam eden pazarlığı üzerine yeni bir teklif yapma, birinin dünürlüğü üzerine dünürlükte bulunma fiilleri örnek verilebilir. Çünkü Hz. Peygamber (s.a.v.) bu davranışları kesin ve bağlayıcı olarak terkedilmesini istemiştir. ${ }^{139}$

Tenzîhen mekruha gelince, Şâri'in terkedilmesini kesin ve bağlayıcı olmayan bir tarzda istediği fiildir. Helale yakın sayıldığından bu fiili yapmak cezayı gerektirmese de kınanır. Hanefîlerin tenzihen mekruh olarak değerlendirdiği bu kavram, cumhurun mekruh dediğine karşılık gelmektedir. ${ }^{140} \mathrm{Bu}$ tür mekruha camiye gidecek kimsenin soğan ve sarımsak gibi kokan şeyleri yemesi örnek verilebilir. ${ }^{141}$

Hanefi mezhebi terminolojisinde "mekrûh" ifadesi kayıtsız mutlak kullanıldığı zaman Ebû Hanîfe ve Ebû Yûsuf'a göre harama yakın (tahrimen) mekruh, İmam Muhammed'e göre ise haram manasına kullanılmaktadır. ${ }^{142}$

İbnü'l-Hümam, İmam Muhammed'in asıl amacının tahrîmen mekruhu inkâr etmenin küfrü gerektirmeyeceğini vurgulamak olduğunu ve gerçekte bu imamlar arasında esasa ilişkin görüş ayrılığı bulunmadığı kanaatindedir. ${ }^{143}$

Sonuç itibariyle mekruh mahbubun zıddı, sevilmeyen şeydir. Bazen harama da mekruh denir. Kudûrî Muhtasar'ındaki "Bir kimse özrü yokken imam cuma günü cuma namazını kıldırmadan evinde öğle namazını kılarsa mekruh olur"144 sözünün, haramdır mânâsına geldiğini beyan etmiştir. Bazen hem tahrimen

136 Gazzâli (ö. 505/1111), el-Müstasfâ min 'ilmi'l-usûl (thk. Muhammed Süleyman el-Eşkar), Beyrut 1417/1997, I, 130-132; Bedrüddîn Muhammed b. Bahadır Abdullah ez-Zerkeşî (ö. 794/1392), elBahru'l-muhît fî usûli'l-fikh (thk. Abdülkadir Abdullah el-'Ânî), Kuveyt 1413/1992, I, 296-303; Koca, "Mekruh", DİA, XXVIII, 582.

137 Sadrușşerîa, et-Tavdîh II, 277; Atar, Fıkıh Usûlü, s. 128.

138 Sadrușșerîa, et-Tavdîh, II, 277; İbn Emîru Hac el-Halebî (879/1474), et-Takrîr ve’t-tahbîr ale’t-Tahrîr fî usûli'l-fıkh (thk. Abdullah Mahmud Muhammed Ömer), Beyrut 1419/1999, II, 103; Koca, "Mekruh", DİA, XXVIII, 582-583.

139 Müslim, "Nikâh”, 38, 49, 52, 54, 56; “Büyû"”, 8; Koca, "Mekruh”, DİA, XXVIII, 582.

140 Koca, "Mekruh", DİA, XXVIII, 582-583.

141 Sadruşşerîa, et-Tavzîh, II, 277; Koca, "Mekruh", DİA, XXVIII, 582-583.

142 Abdullah b. Mahmud el-Mevsılî (ö. 683/1284), el-Muhtâr li'l-fetvâ (thk. Sâid Bekdaş), Beyrut1433/2012, s. 463; İbnü'l-Hümâm (ö. 861/1458), et-Tahrîr fî usûli'l-fikh, Mısır 1351, s. 217.

143 Sadruşşerîa, et-Tavzîh, II, 277; İbnü'l-Hümâm, et-Tahrîr fî usûli'l-fıkh, s. 217. İbn Emîru Hac, etTakrîr ve’t-tahbîr ale’t-Tahrîr fî usûli'l-fıkh, II, 103; Koca, “Mekruh”, DİA, XXVIII, 582-583.

144 Kudûrî, Muhtasaru'l-Kudûrî, s. 52. 
mekruh, hem de tenzihen mekruh için kullanılır. Tahrimen mekruh; harama yakın olan mekrûhtur. İmam Muhammed, ona zannî haram demiştir. Tenzîhen mekruh, yapılması yapılmamasından evlâ olan şeydir. Müterâdifi, hilâf-ı evlâdır. Yani zannî delil ile ispat edilen tenzihen mekruhun derecesi, terk-i evlâdır. ${ }^{145}$

Yukarıda da açıklandığı gibi mekruh terkedilmesi yapılmasına tercih edilen fiiller için kullanılmaktadır. Bu manada lâ be'se, mekruhun müteradifi hilâfı evlâ ve zanni delil ile ispat edilen tenzihen mekruhun derecesi, terk-i evlâ anlamlarına gelir.

Fıkıh literatüründe lâ be’se'nin "mekruh" manasına geldiği örnekler:

Ebû Hanîfe'ye göre, veled-i zinanın imamlık yapmasında, fıkıh bilgisi varsa ve iyi Kur'ân okuyorsa bir sakınca yoktur (lâ be'se), ama başkasının imamlık yapması daha iyidir. Söz konusu hüküm bedevinin ve kölenin imamlığı konusunda da bulunduğu rivayet edilmiştir. ${ }^{146}$ İmam Muhammed'e göre de "namazda secde mahallinin düzeltilmesi hususunda namaz kllanın bir defa düzeltmesinde bir sakınca yoktur (lâ be'se), fakat terk etmesi daha iyidir" şeklinde beyanda bulunmuştur. ${ }^{147}$

Bir başka örnekte ise Hanefîlere göre sadece cuma günü oruç tutulmasında bir sakınca yoktur (lâ be'se). İhtiyaten Cuma gününe ek olarak Cumartesi de oruç tutmanın uygun olacağı hükmü verilmiștir. ${ }^{148}$

$\mathrm{Bu}$ konuda rivayet edilen hadislerde bunu görmek mümkündür. Cabir'e (r.a.) "Hz. Peygamber (s.a.v.) Cuma günü oruç tutmayı yasakladı mı” diye soruldu, o da "evet" diye cevap vermiștir. ${ }^{149}$

Bir başka rivayette ise Hz. Peygamber (s.a.v.) bir Cuma günü Cüveyriye bintü Hâris (r.a.) oruçlu iken kendisine uğradı ve "dün oruç tutmuş muydun" diye sordu, o da "hayır" demiş, Hz. Peygamber (s.a.v) "yarın oruç tutmayı düşünüyor musun" dedi, o da "hayır" demiş, bunu üzerine "öyleyse orucunu boz" buyurmuştur. ${ }^{150}$

$\mathrm{Bu}$ ifade ve rivayetlerden sadece Cuma günü oruç tutmamanın evlâ (tercihe şayan) olduğu, her şeye rağmen tutulursa da mekruh olduğu anlaşılmaktadır. Söz konusu yerde lâ be'se kavramının mekrûh/hilâf-ı evlâ manasına geldiği görülmektedir.

\footnotetext{
145 İbn Nüceym, el-Bahru'r-râik, II, 33; İbn Âbidîn, Reddü'l-Muhtâr, I, 438-439.

146 Muhammed b. Hasan eş-Şeybânî, el-Hucce alêhli'l-Medîne (thk. Seyyid Hasen el-Keylânî), Beyrut 1983, I, 129; Mevsılî, el-Muhtâr, s. 119; Dilek, Uğur Bekir, İslam Hukuk Metodolojisinde Teklifi Hüküm Terimleri, Konya 2010, s. 188 (Basılmamış Doktora Tezi, T.C. Selçuk Üniversitesi Sosyal Bilimler Enstitüsü Temel İslam Bilimleri Bölümü İslam Hukuku Anabilim Dalı).

147 Muhammed b. Hasen eş-Şeybânî, el-Asl, I, 33-34; Dilek, İslam Hukuk Metodolojisinde Teklifi Hüküm Terimleri, s. 188-189.

148 Ayrıntı ve deliller için bk. Mergînânî, Kitâbu't-Tecnîs, II, 418-419.

149 Buhârî "Savm", 62.

150 Buhârî "Savm", 62.
} 
Yukarıda verilen örneklerden "bir sakınca yoktur (lâ be'se)" ifadesinin mekruh olduğu anlaşılmaktadır. Zira veled-i zinanın imameti, ${ }^{151}$ namazda secde mahallinin düzeltilmesi ${ }^{152}$ ve sadece Cuma günü oruç tutmanın hükmü mekruhtur.

Hilâf-ı evlâ ifadesi her ne kadar bazı âlimlere göre mekruhun müradifi olarak kabul edilse de lâ be'se gibi değișik kullanımlara sahip bir kavram olması sebebiyle özel bir başlıkta incelenmesi daha yararlı olacaktır. Zira hilâf-ı evlâ lafzı da incelemiş olduğumuz lâ be'se ile bazı yerlerde aynı anlama gelmektedir. Şimdi bu kavramın incelenmesine geçebiliriz.

\section{Hılâf-ı Evlân ${ }^{153}$}

Hilâf-ı evlâ ifadesinin, lâ be'se kavramı ile yakın ilgisi bulunmaktadır.

Terim olarak hilâf-ı evlâ "Şer'an mendûb ve müstehab gibi fiilleri terk etmek" şeklinde tanımlanmıştır. 154

Yapılması evlâ olanın yani müstehabın terk edilmesi anlamına gelen hilâf-ı evlâya, hilâf-ı edeb, terk-i evlâ ve zıdd-ı evlâ da denilir. ${ }^{155}$

Hanefilerden İbnü'l-Hümâm, mekruh ile hilâf-ı evlâ'yı karşılaştırıp, ikisinin ayrı kavramlar olduğunu şöyle açıklamıştır: Hilâf-ı evlâ'da herhangi bir yasak siygası yoktur, kuşluk namazını terk etmek bunun örneğidir, tenzîhen mekruhta ise bir yasak siygası vardır. ${ }^{156}$ İbn Nüceym müstehabın terkedilmesi mekruhluğu gerektirmez, zira mekruh için özel bir delilin olması gerekir. ${ }^{157}$

Şafiîler, mekruh ile hilâf-ı evlâyı karşılaştırmışlar ve aralarındaki farkı şöyle belirtmişlerdir: Eğer bir fiilin yapılması terk edilmesinden evlâ olur ve terk edilmesi hususunda "şunu yapmayın" veya "size şu eylemi yapmayı yasaklıyorum" gibi özel bir nehiy olursa mekruh, özel bir nehiy değil de genel bir nehiy olursa hilâf-ı evlâ olur. İşlenmemesi hakkında özel bir nehiy olmadığı için hilâf-ı evlâ, kerahet derecesine ulaşmaz. ${ }^{158}$

Hanbelîler de bu hususta Şâfiîler ile aynı kanaattedir. ${ }^{159}$ Malikiler ise Şafîiler'den farklı olarak bir şeyin yapılması hususundaki talebin şiddetini dikkate

151 Mevsllî, el-Muhtâr, s. 119.

152 Mevsllî, el-Muhtâr, s. 122.

$153 \mathrm{Bu}$ konu, başka bir yazıda müstakil olarak ele alınacaktır, onun için kısa ve birkaç örnekle yetinilecektir.

154 Abdürrezzak, Hilâfu Evlâ, s. 41.

155 Dilek, İslam Hukuk Metodolojisinde Teklifi Hüküm Terimleri, s. 150.

156 İbnü'l-Hümâm, et-Tahrîr fî usûli'l-fikh, Mısır h. 1351, s. 257; İbn Âbidîn, Reddü'l-muhtâr (thk. Husamüddin b. Muhammed Sâlih Farfur), I, 412-413.

157 İbn Nüceym, el-Bahru'r-râik, II, 248; Geniş bilgi içi bk. İbn Âbidîn, Muhammed Emîn, Reddü’l-muhtâr (thk. Husamüddin b. Muhammed Sâlih Farfur), IV, 185-188, 202.

158 Cüveynî, İmamu'l-Harameyn (ö. 478/1085), Nihâyetü'l-matlab fî dirâyeti'l-mezheb (thk. Abdülazim Mahmude d-Dib), Beyrut 2007, III, 372; Zerkeşî, el-Bahru'l-muhît, I, 302; İbn Halûlû, Ahmed b. Abdurrahman b. Musa ez-Zelîtînî el-Karavî, ez-Ziyâü'l-lâmî fî şerhi Cem'i'l-cevâmi' (thk. Abdülkerim b. Ali b. Muhammed Nemle), Riyad 1999, I, 181-182; Dilek, İslam Hukuk Metodolojisinde Teklifi Hüküm Terimleri, s. 150.

159 İbn Bedrân, Abdülkadir b. Ahmed. (ö. 1346/1927), el-Medhal ilâ mezhebi'l-İmâm Ahmed b. Hanbel (thk. Abdullah b. Abdülmuhsin Türki), Beyrut 1985, s. 63-64. Dilek, İslam Hukuk Metodolojisinde Teklifi Hüküm Terimleri, s. 150. 
almışlar, sünnet-i müekkede gibi talebi şiddetli olanın terk edilmesine mekruh, talebi șiddetli olmayanın terk edilmesine ise hilâf-ı evlâ demișlerdir. ${ }^{160}$

Buradan anlaşıldığı kadarıyla hılâf-ı evlâ: "Hakkında açık bir nass olmayan ve yapılması terk edilmesine tercih edilen şeydir," şeklinde bir sonuca ulaşmak mümkündür.

Şimdide lâ be'se'nin hilâf-ı evlâ ile aynı manaya geldiği yerlerin örneklerine geçebiliriz.

Fıkıh literatüründe lâ be’se'nin "hilâf-ı evlâ" manasına geldiği örnekler:

Oturmuş konuşmakta olan bir kişinin sırtına doğru namaz kılmakta bir sakınca yoktur (lâ be'se).161 Çünkü sahih bir senetle bildirildiğine göre, İbn Ömer (r.a.) bazı yolculuklarında âzatlı kölesi Nafi'yi (ö. 117/735) kendisine sütre yaparak sırtına doğru namaz kılmıştır. ${ }^{162}$ Fakat yüzüne doğru namaz kılmak mekruhtur. ${ }^{163}$ Ancak imkân varsa huşuyu zedeleme endişesi ile başka yerde namaz kılmak, konuşan bir kişinin sırtına doğru yönelerek namaz kılmamak daha doğru olduğu düşünülebilir. Zira burada "lâ be’se" ifadesinin "hılâf-ı evlâ" manasına alınması daha uygun görülmektedir.

Namaz kılınan sergi ile ilgili meselede, canlı resmi bulunan bir sergi üzerinde resim üzerine secde etmemek kaydıyla namaz kılmanın bir sakıncasının olmayacağı (lâ be'se) belirtilmiştir. ${ }^{164}$ Çünkü bu durumda resim ayakların altında kalıp aşağılandığı/tahfif edildiği için ona saygı gösterilmiş olmuyor. Zira resimlere tapmayı andırdı̆̆ı için üzerlerine secde edilmez. Mergînânî, "Üzerine secde edilsin edilmesin resim bulunan herhangi bir şey üzerinde namaz kılmak mekruhtur" demiştir. Fakat ulemanın çoğuna göre, resimlerin baş tarafı olmazsa üzerine secde edilmesinde de bir kerahetin söz konusu olmayacağı söylenmiştir. ${ }^{165}$

Bütün bu tartışmalara rağmen canlı resmi bulunan bir sergi üzerine secde edilmesi terk-i evlâdır. Yani söz konusu sergi üzerinde namaz kılmak hilâf-ı evlâdır.

Ebû Hanîfe'ye göre kırsal yerlerde bir binayı Mecusilere mabet, kilise veya havra yapmak ya da orada şarap satılmak üzere kiraya verilmesinde bir sakınca yoktur (lâ be'se). Zira söz konusu kira akdi menfaat üzerine yapılmış bir akittir. Bunda bir masiyet yoktur. Masiyet, kiracının fiilindedir. 0 da bu fiillerinde muhayyerdir. Dolayısıyla bu masiyet fiillerinin mal sahibi ile bir ilişkisi yoktur. İmameyn'e göre ise bunların hiç biri için kiraya veremez. Çünkü bunların hepsi günah işlemeye yardım etmektir. ${ }^{166}$

160 Hattâb er-Ruaynî, Ebû Abdullah Şemseddin Muhammed (ö. 954/1547), Mevâhibü’l-celîl li-şerhi Muhtasari Halîl, Riyad 2003, I, 56.

161 Muhammed b. Hasen eș-Şeybânî, el-Câmiu's-sağîr, s. 86; İbn Mâze, Şerhu'l-Câmi'i's-sağîr, s. 144; Mergînânî, el-Hidâye, I, 235; farklı görüş ve tartışmalar için bk. İbn Nüceym, el-Bahru'r-râik, II, 55.

162 İbn Ebî Şeybe, el-Musannef, Beyrut 1409/198, I, 279.

163 el-Feteva'l-Hindiyye, Dâru'l-Fikir 1411/1991, I, 108.

164 Muhammed b. Hasen eş-Șeybânî, el-Câmi'u's-sağîr, s. 88.

165 Mergînânî, el-Hidâye, I, 235; Zeylâî, Tebyînü'l-hakâik, I, 417; İbn Nüceym, el-Bahru'r-râik, II, 56; elFetâva'l-Hindiyye, I, 107.

166 Muhammed b. Hasen eş-Şeybânî, el-Câmi'u’s-sağîr, s. 534; Mergînânî, el-Hidâye, IV, 162-163. 
İmâmeyn'e göre "kısrağın artığı temizdir, çünkü o, eti yenen bir hayvandır." $A s l$ da zikredildiğine göre kısrağın artığının hükmü konusunda ihtilaf belirtilmeden "bir sakınca yoktur (lâ be'se)" ifadesi kullanılmıștır. Serahsi'nin Mebsût'unda Zahiru'r-rivaye'den alıntı yapılarak kısrağın artığının temiz olduğu zikredilmiştir. ${ }^{167}$ Sahih olan görüş ve rivayete göre bu hususta Ebû Hanîfe de imameyle aynı görüştedir. ${ }^{168}$

Şarap imalatçısı olduğu bilinen birisine üzüm satmakta bir sakınca yoktur (lâ be'se). Çünkü onun şarap yapacağı kesin olmadığı için bu satışla bizzat masiyet işlenmiş değildir. 169 Burada lâ be'se ifadesi hilâf-1 evla demek olduğu anlaşılmaktadır, zira evlâ olan satılmamasıdır. ${ }^{170}$

Lâ be'se'nin "yapılmaması daha iyi/terkedilmesi evlâ" manasına geldiğinin örneklerinden biri de bir kişi ziyaret tavafından sonra tavaf ederse, buna nafile veya veda tavafı diye niyet ederse, bu eylem, kişi ihramdan çıktıktan sonra olur ki, bu tavaf; veda tavafı sayllır. Onun veda tavafından sonra da dilediği kadar Mekke'de kalmasında bir sakınca yoktur (lâ be'se), daha sonra Mekke'den ayrılır gider. Ancak efdal ve evlâ olan kişinin veda tavafını Mekke'den ayrılacağı zaman yapmasıdır. ${ }^{171}$ Veda tavafından sonra Mekke'den ayrılmak tercih edilen davranıștır.

Bütün bu örneklerde lâ be'se, hilâf-ı evlâ "yapılmaması daha iyi/terkedilmesi evlâ" manasına gelmektedir.

\section{Sonuç}

Lâ be'se kavramının yükümlülük kuramı (ef'âl-i mükellefîn) ile çok yakın bir ilgisi vardır. Söz konusu kategorilerden bir kaçını birden ifade edecek şekilde genel bir anlamda kullanıldığı görülür. Müradifi sayılan hilâf-ı evlâ gibi diğer bazı kavramlarla birlikte bu kavram yükümlülük kuramı ile ilgili sistemi muhafaza maksadıyla doğrudan ef'âl-i mükellefin kategorisine dâhil edilmemiştir.

İlk dönemden itibaren kaleme alınan fikıh literatüründe lâ be'se kavramının farklı manalarda kullanıldığı tespit edilmiștir. Lâ be'se, "mükellefin söz konusu eylemi yapmasında bir sakınca yoktur" anlamına gelse de bunun geçerli küllî bir ilke olmadığı; ilgili konunun caiz olduğuna dair bir delilin mevcudiyeti halinde mükellefin o eylemi yapıp yapmamada muhayyer olduğu; delilin bulunmadığı hallerde ise "terk-i evlâdır" şeklinde anlaşılması gerektiği sonucuna varılmıştır.

Hanefilerin, lâ be'se kavramını mubah veya terk-i evlâ anlamında kullandıkları, fakat bununla müstehabdan başka bir şey kastettikleri anlaşılmıştır.

Lâ be'se kavramının kullanımlarından birinin de mendûb manasına geldiği tespit edilmiştir.

167 Şemsüddin Ebû Bekr Muhammed b. Ebî Sehl es-Serhsî (ö. 483/1090), el-Mebsut (thk. Halil Muhyiddin el-Mîs), Beyrut 1421/2000, I, 50.

168 Aynî, el-Binâye, I, 496.

169 Mergînânî, el-Hidâye, IV, 162.

170 Mergînânî, el-Hidâye, IV, 162.

171 Muhammed b. Hasan eş-Şeybânî, el-Asl, II, 378-379 (II, 319-320); Nasîruddîn en-Nakîb, elMezâhibu'l-Hanefî, I, 377-378. 
İmam Muhammed'e göre, bir meselenin helalliği ve haramlığı hususunda nass varsa onun hükmünün belli olduğu, nass yoksa helallerde lâ be'se, haramlarda ise mekrûh ifadesinin kullanıldığı görülmüştür.

Lâ be'se'nin mekruh manasına da geldiği tespit edilmiştir. Mesela İmam Şafiî̀ye göre, lâ be’se kelimesinin, mekruh veya müstehab değil, bizzat caiz manasında kullanıldığı sonucuna varılmıştır.

Malikilere göre, lâ be’se, çoğunlukla mubah veya müstehab manasına gelmekte olup mubahlık ifade eden lafizlardandır. Dolayısıyla mükellefin, mubah fiilleri yaptığı yerlerde; lâ be'se, denildiği görülmektedir. Yine Malikilerden bazı müellifler lâ be'se'nin sadece mubah fiiller için kullanılabileceği, müstehab manası ifade etmeyeceği kanaatini belirtmiş olsa da, onların bu kavramı müstehab manasına da kullandıkları tespit edilmiştir.

Hanbelîlere göre lâ be'se'nin mubahlık ifade eden kavramlardan olduğu tespit edilmiştir. Hanbelî mezhebi alimlerine göre, lâ be'se ve isterse yapar (in şâe fa'ale) lafizlarının aynı anlamı ifade ettiği ve mubahlık manasına geldiğine dair icmanın olduğu tespit edilmiştir.

Hanefi fikıh literatüründe verilen birçok örnekle lâ be'se'nin müstehab ve mendub manasına kullanıldığı sonucu çıkarılmıştır.

Hilâf-ı evlâ ve terk-i evlâ ifadelerinin, lâ be'se kavramı ile yakın ilgisi bulunmaktadır. Terk-i evlâ hükmünde olan bir fiilin özür sebebiyle mubah manasına geldiği sonucuna varılmıştır. Tenzihen mekruhun derecesinin, terk-i evlâdır olduğu, lâ be'se anlamında kullanıldığı örneklerde görülmüştür. Lâ be'se ifadesi bazen hem mekruh hem de hilâf-ı evlâ manasına gelir. Netice olarak lâ be'se, hilâf-ı evlâ, terk-i evlâ, mekruh, müstehab ve mubah anlamlarına gelmektedir.

Çok genel geçer bir ilke olmasa da lâ be'se kavramı ile ilgili şöyle iki ilke çıkarılabilir: Lâ be'se muamelat konularında mubah, ibadet konularında hilâf-ı evlâ manasında kullanılır.

\section{Kaynakça}

Abdülaziz el-Buhârî (ö. 730/1330), Keșfü'l-esrâr 'an Usûli Fahri'l-İslâm el-Bezdevî (thk. Muhammed elMutasım Billah el-Bağdâdî), Beyru 1414/1994.

Abdürrezzak Abdurrahman Salim Ebû Umra, Hilâfu Evlâ Inde'l-usûliyyîn diraseten usûliyyeten mukâraneten, el-Âmu'l-Câmi'î 1432/2011.

Ahmed b. Ali b. Hacer el-Askalânî (ö. 852/1449), Fethu'l-bârîșerhu Sahîhi'l-Buhârî, Beyrut 1399.

Ahmed b. Ebî Sehl es-Serahsî (ö. 483/1090), Usûlü's-Serahsî (thk. Ebû'l-Vefâ el-Efkânî), Beyrut ts.

Ahmed b. Muhammed el-Kudûrî (ö. 428/1037), Muhtasaru'l-Kudûrî (thk. Said Bekdâş), Beyrut $1435 / 2014$.

Ahmed b. Muhammed Nasîruddîn en-Nakîb, el-Mezâhibu'l-Hanefî, Riyad 1422/2001, Mektebetü'r-Rüşd.

Alauddîn Ebî'l-Hasen Ali b. Süleyman el-Madâvî, el-İnsâffî marifeti'r-râcih min'l-hilâf alâ mezhebi'l-İmam Ahmed $b$. Hanbel, ts. Dâru İhyâi't-Türâsi'l-Arâbî.

Alauddin Ebû Bekir b. Mesud el-Kâsânî (ö. 587/1191), Bedâi'u's-sanâi' (Ali Muhammed Muavviz-Adil Ahmed Abdülmevcud), Beyrut 1424/2003.

Alauddin Muhammed b. Ahmed es-Semerkandî (ö. 539/1144), Mîzânü'l-usûl fî netâici'l-ukûl (thk. Zeki Abdülber), Katar 1404/1984.

Ali b. Halef b. Abdülmelik b. Battâl el-Bekrî el-Kurtubî (ö. 449/1057), Şerhu Sahîhi'l-Buhârî, Riyad $1423 / 2003$.

Ali b. Muhammed e-Şerîf el-Cürcânî (ö. 818/1415), Kitabü't-ta'rifât (thk. Muhammed Abdurrahman elMara'şlî), Beyrut 14124/2003.

Ali Cuma Muhammed, el-Hükmü'ş-Şer'ıyyu, Kahire 1427/2006. 
Âlim Muhammed b. Hamza'nın (ö. 1204/1706) lâ be'se kavramı üzerine "Risale fî isti'mali lâ be'se, İstanbul Üniversitesi Merkez Kütüphanesi, Nadir Eserler, Arapça bölümü, nr. 1502.

Atar, Fahrettin, Flkıh Usûlü, İstanbul 1992.

Bedruddin Ebû Muhammed Mahmud b. Ahmed el-Aynî (ö. 855/1451), el-Binâye șerhu'l-Hidâye, Beyrut $1420 / 2000$.

------, Şerhu Süneni Ebî Dâvûd (Ebû Münzir Halid b. İbrahim el-Mısrî), Riyad 1420/1999.

Bedrüddîn Muhammed b. Bahadır Abdullah ez-Zerkeșî (ö. 794/1392), el-Bahru'l-muhît fî usûli'l-fikh (thk. Abdülkadir Abdullah el-'Ânî), Kuveyt 1413/1992.

Beyânûnî, Muhammed Ebü'l-Feth, "Hüküm", DİA, İstanbul 1998, XVIII.

Beyhakî, es-Sünenü'l-kübrâ (thk. Muhammed Abdülkadir Ata), Beyrut 1424/2003.

Burhânuddîn Ebü'l-Hasen Ali b. Ebî Bekr el-Mergînânî, el-Hidâye șerhu Bidâtetü'l-mübtedî (thk. Ahmed Mahmud eş-Şehâde), Dımeşk 1427/2006 (Dâru'l-Farfur).

-----, Kitabu't-Tecnîs ve'l-mezîd (thk. Muhammed Emin Hakkı), Beyrut 1424/2004.

Cemalüddin Ebû Muhammed Abdullah b. Yusuf b. Muhammed el-Zeylaî (ö. 762/1361), Nasbu'r-râye liehâdîsi'l-Hidâye (thk. Muhammed Avvâme), Beyrut 1418/1997.

Cemâlüddîn Osman b. Ömer İbnü'l-Hâcib (ö. 646/1249), Muhtasaru'l-Münteha'l-usûlî, Dâru'l-Kütübi'lİlmiyye, Beyrut 1983.

Cici, Recep, Âlim Muhammed b. Hamza'nın Fıkıh Risâleleri, Bursa 2006.

Cüveynî, İmamu'l-Harameyn (ö. 478/1085), Nihayetü'l-matlab fi dirâyeti'l-mezheb (thk. Abdülazim Mahmude d-Dib), Beyrut 2007.

Dilek, Uğur Bekir, İslam Hukuk Metodolojisinde Teklifi Hüküm Terimleri, Konya 2010, s. 188 (Basılmamıș Doktora Tezi, T.C. Selçuk Üniversitesi Sosyal Bilimler Enstitüsü Temel İslam Bilimleri Bölümü İslam Hukuku Anabilim Dalı).

Dönmez, İbrahim Kâfi, “Mubah", DíA, İstanbul 2005, XXX.

Ebû Abdillah el-Hasen b. Hâmid, Tehzîbu'l-ecvibe (thk. Subhî es-Sâmirâî), Mektebetü'n-nahda $1408 / 1988$.

Ebû Zekeriyya Yahya b. Şeref en-Nevevî (ö. 676/1277), el-Minhâc șerhu Sahîhi Müslim, Beyrut $1407 / 1987$.

Ebû'l-Berekât Abdullah b. Ahmed en-Nesefî (ö. 710/1310), el-Kâfí șerhu'l-Vâfî, Köprülü Ktp., Fazıl Ahmed Pașa Bölümü, nr. 612.

Ebü'l-Fazl Abdullah b. Mahmud b. Mahmud el-Mevslî (v. 683/1284), el-íhtiyâr lita'lîli'l-Muhtâr (thk. Muhammed Muhyiddin Abdülhamid), Kahire 1372/1952.

-----, el-Muhtâr li'l-fetvâ (thk. Sâid Bekdaș), Beyrut1433/2012.

-----, el-Feteva'l-Hindiyye, Dâru'l-Fikir 1411/1991.

------, el-Külliyyât (thk. Adnan Derviș-Muhammed el-Mısrî), Beyrut 1432/2011.

Erdoğan, Mehmet, Fikıh ve Hukuk Terimleri Sözlüğü, İstanbul 2005.

Erkal, Mehmet, "Ganimet", DIA, İstanbul 1996, XIII.

Fahreddin Osman b. Ali ez-Zeylaî (ö. 743/1342), Tebyînu'l-hakâik șehu Kenzü’d-dekâik (thk. Ahmed İzzu İnaye), Beyrut 1420/2000.

Fahruddîn Muhammed b. Ömer er-Râzî, el-Mahsûl fî 'ilmi'l-usûl (thk. Taha Cabir Feyyaz el-Alvânî), Riyat $1400 / 1980$.

------, el-Mahsûl fí ilmi'l-usûl (thk. Taha Cabir Feyyâz el-Alvânî), Beyrut 1412/1992.

Feyyûmî, el-Misbâhu'l-münîr, Kum h. 1405.

Feyyûmî, el-Misbâhu'l-münîr, Kum h. 1405.

Hâdimî, Ebû Saîd Muhammed, Menâfi'u'd-dekâik fî șerhi Mecâmi'ı'l-hakâik, İstanbul 1303.

Hasen b. Ammâr b. Ali eș-Șürunbilâlî (ö. 994/1069), İmdâdü'l-fettâh șerhu Nuri'l-îzâh (thk. Beșşâr Bekrî Arabî), Dımașk ts.

Hasen b. Ammar b. Ali eş-Șürunbülâlî (ö. 1069/1659), İmdâdu'l-fettah şerhu Nûri'l-îzâh ve necâti'l-ervâh (thk. Beşşar Bekrî Arabî), ts.

Hatipoğlu, Haydar, Sünen-i İbni Mâce Tercemesi ve Șerhi, İstanbul 2012.

Hattâb er-Ruaynî, Ebû Abdullah Șemseddin Muhammed (ö. 954/1547), Mevâhibü'l-celîl li-șerhi Muhtasari Halîl, Riyad 2003.

Heyet, Kur'ân-ı Kerim ve Açılamalı Meâli, Türkiye Diyanet Vakfı Yayınları, Ankara 2005.

İbn Âbidîn, Muhammed Emîn (ö. 1252/1836), Reddü'l-muhtâr ale'd-Dürri'l-muhtâr șerhu Tenvîri'l-ebsâr (thk. Husamüddin b. Muhammed Sâlih Farfur), Dımeșk 1421/2000.

İbn Bedrân, Abdülkadir b. Ahmed. (ö. 1346/1927), el-Medhal ilâ mezhebi'l-Imâm Ahmed b. Hanbel (thk. Abdullah b. Abdülmuhsin Türki), Beyrut 1985.

İbn Emîru Hac el-Halebî (879/1474), et-Takrîr ve't-tahbîr ale't-Tahrîr fî usûli'l-fikh (thk. Abdullah Mahmud Muhammed Ömer), Beyrut 1419/1999.

İbn Fâris, Mu'cemu mekâyisi'l-lüğa (thk. Abdüsselam Muhammed Harun), Beyrut 1399/1979. 
İbn Halûlû, Ahmed b. Abdurrahman b. Musa ez-Zelîtînî el-Karavî, ez-Ziyâü'l-lâmî fî șerhi Cem 'i'l-cevâmi' (thk. Abdülkerim b. Ali b. Muhammed Nemle), Riyad 1999.

İbn Manzûr (ö. 711/1311), Lisânu'l-Arab, Dâru Sâdır, ts.

İbn Nüceym (v 870/1563), el-Bahru'r-râik şerhu Kenzi'd-dekâik (thk. Zekeriya Umeyrât), Beyrut $1418 / 1997$.

İbnü'l-Hümâm (ö. 861/1457), Şerhu Fethi'l-Kadîr (thk. Abdurrezzâk Gâlib el-Mehdî), Beyrut 1415/1995.

- et-Tahrîr fî usûli'l-fikh, Kahire 1351.

İbrahim Muhammed Selkînî, el-Müyesser fí usûli'l-fikh, Beyrut 1411/1991.

İsmail b. Hammâd el-Cevherî (ö. 393/1003), es-Sihâh (thk. Halil Memun Şeyha), Beyrut 1426/2005.

Koca, Ferhat, "Mekrûh", DİA, Ankara 2003, XXVIII.

-----, "Mendûb", DİA, Ankara 2004.

Köse, Saffet, İslâm Hukukuna Giriș, İstanbul 2014.

Mahmud Hâmid Osman, el-Kâmûsu'l-mubîn fîstlâhâti'l-usûliyyîn, Riyat 1423/2002.

Malik b. Enes (ö. 179/795), el-Muvatta, Hasan b. Şeybân rivayeti (thk. Takiyüddin en-Nedvî), Beyrut $1413 / 1992$.

Meryem Muhammed Salih ez-Zâfirî, Mustelahâtu'l-mezâhibi'l-fikhiyye, Beyrut 1422/2002 (Dâru İbni Hazm).

Molla Hüsrev, Muhammed b. Ferâmuz (ö. 885/1485), Mir'âtü'l-usûl şerhu Mirkâtü'l-vusûl, Ergin Kitabevi, İstanbul ts.

Muhammed b. Ahmed el-Hatîb eş-Şirbînî (ö. 977/1569), Muğni'l-muhtâc ilâ ma'rifeti meânî elfâzi'lMinhâc, Beyrut 1415/1994, Dâru'l-Kütübi'l-İlmiyye.

Muhammed b. Hasan eş-Şeybânî (ö. 189/805), el-Hucce alêhli'l-Medîne (thk. Seyyid Hasen el-Keylânî), Beyrut 1983.

------, el-Asl, (thk. Ebü'l-Vefâ el-Efgânî), Beyrut 1410/1990.

-----, el-Câmiu's-sağîr , Beyrut 1406/1986.

Muhammed b. Muhammed b. Muhammed el-Gazâlî (ö. 505/1111), el-Menhûl min ta'lîkâti'l-usûl (thk. Muhammed Hasen Heyto), Dâru'l-Fikr, Dımeșk 1400/1980.

------, el-Mustasfâ min 'ilmi'l-usûl (thk. Muhammed Süleyman el-Eşkar), Beyrut 1418/1997.

Muhammed b. Mükerrem İbn Manzûr, Lisânü'l-Arab, Dâru Sâdr, Beyrut ts.

Muhammed b. Sâlih b. Muhammed el-Useymîn, eș-Șerhu'l-mümteni' alâ Zadi'l-müstekni', Dâru İbni'lCevzî, 1422.

Muhammed Bedruddin Mahmud b. Ahmed el-Aynî (ö. 855/1451), Umdetü'l-kâri şerhu Sahîhi'l-Buhârî (thk. Abdullah Mahmud Muhammed Ömer), Beyrut 1421/2001.

Muhammed İbrahim el-Hafâdî, Mu'cmu garîbi'l-fikh ve'l-usûl, Kahire 1430/2009.

Muhammed Murtaza el-Hüseynî ez-Zebîdî (ö. 1205/1790), Tâcu'l-'arûs, Daru'l-Hidaye, ts.

Muhammed Takî el-Osmânî, Buhusun fî Kazâyâ fikhiyye muâsıra, Karatşî, ts., Mektebetü Dâri'l-Ulûm.

Muhibbullah b. Abdişşekûr (ö. 1119/), Müsellemü's-sübût (thk. Abdullah Mahmud Muhammed Ömer), Beyrut 1423/2002.

Muhyiddin Ebû Zekeriyya Yahya b. Șeref en-Nevevî (ö. 676/1277), Minhâcu't-tâlibîn (thk. Muhammed Tahir Şaban), Beyrut 1426/2005.

Necmüddîn Hahmed b. Hamdân b. Şebîb b. Hamdân en-Nemrî, Sifetü'l-fetvâ ve'l-müftî ve'l-müsteftî, h. 1397.

Nesefî, Flkhu'l-Keydânî, İstanbul Millet Ktp., nr. 1178.

Ögüt, Salim, "Ef'âl-i Mükellefîn", DIA, İstanbul 1994, X.

Ömer b. Abdülaziz b. el-Mâze (ö. 536/1141), Serhu'l-Câmi'i's-sağîr, Beyrut 1427/2006.

Sadrüşşerîa Ubeydullah b. Mes'ûd el-Mahbûbî (ö. 747/1346), et-Tavdîh șerhu't-Tenkîh (thk. Muhammed Adnan Derviş), Beyrut 1419/1998.

Salih b. Abdissemî el-Âbî (ö. 1335/1917), es-Semeru'd-dânî fì takrîbi'd-dânî şerhu Risâleti İbn Ebî Zeyd elKayrevânî, Beyrut, ts., el-Mektebetü’s-Sekâfiyye.

Semâ'în Halidî, "el-Menhecü'l-Fıkhî li'l-İmam-ı Malik fi'l-Muvatta", İslam Hukuku Araştırmaları Dergisi, sy. 9, Konya 2007.

Seyfüddîn Ebü'l-Hasen Ali el-Âmidî, el-İhkâm fî usûli'l-ahkâm, Kahire 1968.

Şahin, Osman, İslam Hukunda Fetva Usulü, Samsun 2002, s. 37 (Basılmamış Doktora Tezi, Ondokuz Mayıs Üniversitesi Sosyal Bilimler Enstitüsü).

Șemsüddin Ebû Abdillah b. Muhammed b. Abdirrahman et-Tırablusî el-Mağribî (ö. 954/1547), Mevâhibu'l-celîl fî șerhi Muhtasari'l-Halîl, Beyrut 1412/1992.

Şemsüddin Ebû Bekr Muhammed b. Ebî Sehl es-Serhsî (ö. 483/1090), Mebsut (thk. Halil Muhyiddin elMîs), Beyrut 1421/2000.

Şihabuddin Ahmed b. İdris el-Karâfí (ö. 684/1285), ez-Zehîra, Beyrut 1994.

Şihabuddîn Ahmed b. Muhammed el-Hamevî (ö. 1098/1687), Gamzu 'uyûni'l-besâir șerhu kitabi'l-Eşbâh ve'n-nezâir, Beyrut 1405/1985 (Dâru'l-Kütübi'l-İlmiyye). 
Taftâzânî, Sa'dudîn Mes'ûd b. Ömer, (ö. 793/1390), et-Telvîh 'ale't-Tavdîh, Dâru'l-Kütübi'l-İlmiyye, Beyrut, ts.

Takıyyuddin Ebû'l-Feth Muhammed b. Ali b. Vehb b. Mutî‘ el-Kușeyrî İbn Dakîki'l-'Iyd (ö. 702/1302), İhkâmu'l-ahkâm șerhu Umdedi'l-ahkâm (thk. Mustafa Şeyh Mustafa-Müddesir Sündüs), Müessetü'r-Risale 1426/2005.

Tehânevî, Muhammed b. Ali, Keş̦âfu istlahâti'l-funûn, Dâru'l-Kütübi'l-İlmiyye, Beyrut 1998.

Yaman, Ahmet, "Tenfil", DIA, İstanbul 2011, XL.

Yusuf b. Abdillah b. Abdilber en-Nemrî̂ (ö. 463/1071), el-ístizkâr (thk. Salim Muhammed AtaMuhammed Ali Muavviz), Beyrut 1421/1200.

------, et-Temhîd limâ fíl'-Muvatta min'l-ma'ânî ve'l-esânîd (Mustafa b. Ahmed el-Alevî-Muhammed Abdülkebir el-Bekrî)

Zeydan, Abdülkerim, el-Vecîz fí usûli'l-fikh, Beyrut 1418/1997.

------, el-Medhal, Beyrut 1420/2005.

Zeynüddin Muhammed el-Münâvî (ö. 1031/1622), Feyzu'l-Kadîr șerhu'l-Câmiu's-sağîr, Kahire 1356. 